\title{
The Power of Congress to Limit the Jurisdiction of Federal Courts and the Text of Article III
}

\author{
John Harrison $\dagger$
}

\begin{abstract}
SECTION 1. The judicial Power of the United States, shall be vested in one supreme Court, and in such inferior Courts as the Congress may from time to time ordain and establish. The Judges, both of the supreme and inferior Courts, shall hold their Offices during good Behaviour, and shall, at stated Times, receive for their Services, a Compensation, which shall not be diminished during their Continuance in Office.
\end{abstract}

SECTION 2. The judicial Power shall extend to all Cases, in Law and Equity, arising under this Constitution, the Laws of the United States, and Treaties made, or which shall be made, under their Authority;--to all Cases affecting Ambassadors, other public Ministers and Consuls;- - to all Cases of admiralty and maritime Jurisdiction;-to Controversies to which the United States shall be a Party;-to Controversies between two or more States;-between a State and Citizens of another State;-between Citizens of different States,between Citizens of the same State claiming Lands under Grants of different States, and between a State, or the Citizens thereof, and foreign States, Citizens or Subjects.

In all Cases affecting Ambassadors, other public Ministers and Consuls, and those in which a State shall be Party, the supreme Court shall have original Jurisdiction. In all the other Cases before mentioned, the supreme Court shall have appellate Jurisdiction, both as to Law and Fact, with such

$\dagger$ Associate Professor of Law, University of Virginia. Helpful comments were provided by Steve Calabresi, Jack Goldsmith, George Rutherglen, Ted White, and participants at a workshop at the University of Virginia School of Law. Bill Carnell and Steve Tredennick provided outstanding research assistance.

The title is adapted from an article by the unmoved mover of this debate, Henry M. Hart, Jr., The Power of Congress to Limit the Jurisdiction of Federal Courts: An Exercise in Dialectic, 66 Harv L Rev 1362 (1953). 
Exceptions, and under such Regulations as the Congress shall make. ${ }^{1}$

In the eighteenth century there was a vogue for solving difficult practical problems with complex mechanisms. America's Constitution is such a mechanism. One practical problem to which the Constitution's solution is especially complex is that of law and courts in a federal system, which involves the Constitution's primary sources of intricacy, federalism, and separation of powers. One of the most debated separation of powers questions that arises in this context concerns the extent of Congress's power under Article III to limit the federal courts' jurisdiction. Focusing on the language of the Constitution, and ignoring as much as possible the gloss that has developed, this article defends the traditional view that Congress's authority is substantial.

Part I outlines the debate over the congressional power to limit jurisdiction and describes the current controversy over the bearing of the text on that debate. Part II then shows how a close reading of Article III's language leads most naturally to the traditional view and argues that there are severe textual difficulties with the competing readings. Part III considers the claim that the Constitution's overall structure implies a more restricted congressional power over jurisdiction. I reject that claim, arguing that the constitutional structure underdetermines such matters of fine detail.

\section{THE DEBATE OVER JURISDICTION LIMITATION}

Most of the time Congress treats the federal courts as its partners in government. For example, some of Congress's most memorable assertions of central authority, like the Force Act of 1833 and the Civil Rights Act of 1866, involved expansions of federal judicial competence. ${ }^{2}$ There is also, however, this matter of judicial review, which sometimes makes Congress wish that federal judicial competence were not quite as broad as it is. The two-edged nature of the relationship between Congress and the federal courts came out most clearly during Reconstruction, when Congress, while expanding the reach of federal judicial power, simultaneously manipulated the jurisdictional statutes in order to delay or prevent a pronouncement by the Supreme Court

1 US Const, Art III. Section 2 concludes by providing for jury trial in criminal cases.

2 Force Act of $1833 \S 3,4$ Stat 632, 633-34; Civil Rights Act of 1866 \$ 3, 14 Stat 27, 27. 
on the constitutionality of dubious legislation. ${ }^{3}$ Discussions of the jurisdiction of the federal courts thus involve the questions of both the maximum scope that Congress may give it and the minimum scope to which Congress is permitted to shrink it.

The first phase of the current academic discussion of congressional power to limit federal jurisdiction began with Henry Hart's Dialogue. ${ }^{4}$ For many years no one urged that the text of Article III itself might dispose of the issue, certainly not that the text would dispose of the issue by denying or limiting congressional power. It seemed to be long-standing practice that the federal judiciary did not have all the jurisdiction it might have under the Constitution. Moreover, the Supreme Court had said that Congress's power over the jurisdiction of the inferior federal judiciary was plenary in Sheldon $v$ Sill..$^{5}$ Finally, the Court had also indicated a broad sweep for Congress's power, derived from the Exceptions Clause, to limit the appellate jurisdiction of the Supreme Court. ${ }^{6}$ To academics for whom practice and precedent meant a great deal, and the unglossed text fairly little, the question seemed settled.

Instead, the debate proceeded on other terms. Hart himself thought the overall structure of the Constitution put some limits on Congress's power over the Supreme Court's jurisdiction. ${ }^{7}$ Lawrence Sager, years after Hart, made essentially structural arguments for even stronger limitations. ${ }^{8}$ Other commentators, such as Laurence Tribe, have focused on the ways in which substantive limitations on the government-the "individual rights" provisions of the Constitution-could invalidate congressional at-

${ }^{3}$ See William W. Van Alstyne, A Critical Guide to Ex Parte McCardle, 15 Ariz L Rev 229, 233-44 (1973).

" Henry M. Hart, Jr., The Power of Congress to Limit the Jurisdiction of Federal Courts: An Exercise in Dialectic, 66 Harv L Rev 1362 (1953). Further citation to the Dialogue will be to the third edition of Hart's casebook, Paul M. Bator, et al, Hart and Wechsler's The Federal Courts and the Federal System 393-423 (Foundation 3d ed 1988) ("Hart and Wechsler"), which is more accessible.

Because the academic discussion of this subject is notoriously extensive, I will try to cite only those articles that bear directly on the subject.

s 49 US (8 How) 441, 448-49 (1850).

- Ex Parte McCardle, 74 US (7 Wall) 506, 513-14 (1868). The Exceptions Clause is US Const, Art III, \$2, cl 2.

"Hart and Wechsler at 394 (cited in note 4). Hart's argument was to some extent textual, in that he was interpreting the word "exceptions," but his proposed standard was essentially structural: "The measure is simply that the exceptions must not be such as will destroy the essential role of the Supreme Court in the constitutional plan." Id. The Supreme Court's essential function, if it has one, must be deduced from the design of the Constitution as a whole.

" See Lawrence Gene Sager, Foreword: Constitutional Limitations on Congress' Authority to Regulate the Jurisdiction of the Federal Courts, 95 Harv L Rev 17, 42-68 (1981). 
tempts to curtail federal jurisdiction. ${ }^{9}$ The textual reading underlying this debate-according to which Article III grants Congress broad power over the Supreme Court's appellate jurisdiction and complete power over the lower courts' jurisdiction-has come to be referred to as the orthodox, or traditional, interpretation.

Another phase of the debate opened when Robert Clinton sought to awaken a thesis that had slept through most of the Republic's history. ${ }^{10} \mathrm{He}$ maintains that Article III itself, as originally understood, contains the answers to all these questions. According to Clinton, some federal court, supreme or inferior, must be available to hear and decide every lawsuit described in the list of cases and controversies in Section 2 of Article III. Congress, says Clinton, may use its power to make exceptions to the Supreme Court's appellate jurisdiction only if it makes sure that the excepted cases come within the jurisdiction of some lower federal court: No cases or controversies may be lost, except perhaps a minimal set dropped out for reasons of practical convenience. ${ }^{11}$

Clinton calls his a mandatory theory, apparently for two reasons. First, following Justice Story, he characterizes the Vesting Clause of Article III as a command - a mandate - to Congress. To him, "The judicial Power of the United States shall be vested" means "Congress is hereby commanded to vest the judicial power of the United States." Second, the theory proposes a mandatory

- See Laurence H. Tribe, Jurisdictional Gerrymandering: Zoning Disfavored Rights Out of the Federal Courts, 16 Harv CR-CL L Rev 129, 139-52 (1981). Tribe's article, like much of the academic discussion, was in response to legislative proposals to limit federal jurisdiction on certain controversial topics.

" See Robert N. Clinton, A Mandatory View of Federal Court Jurisdiction: A Guided Quest for the Original Understanding of Article III, $132 \mathrm{U}$ Pa L Rev 741 (1984); Robert N. Clinton, A Mandatory View of Federal Court Jurisdiction: Early Implementation of and Departures from the Constitutional Plan, 86 Colum L Rev 1515 (1986).

"Clinton deduces from the text that the framers

intended to mandate that Congress allocate to the federal judiciary as a whole each and every type of case or controversy defined as part of the judicial power of the United States by section 2, clause 1 of article III, excluding, possibiy, only those cases that Congress deemed to be so trivial that they would pose an unnecessary burden on both the federal judiciary and on the parties forced to litigate in federal court.

Clinton, $132 \mathrm{U} \mathrm{Pa}$ I Rev at 749-50 (cited in note 10) (footnote omitted). The exceptions power "was at most an allocative authority designed to facilitate the creation of inferior federal courts." Id at 753.

${ }^{12}$ See id at 749-50. As mentioned, the main source of this theory is Justice Story's opinion in Martin v Hunter's Lessee, 14 US (1 Wheat) 304 (1816):

The language of [ ] article [III] throughout is manifestly designed to be mandatory upon the legislature. Its obligatory force is so imperative, that congress could not, 
reading in that the Constitution on this issue is mandatory rather than empowering; instead of authorizing Congress to make decisions about federal jurisdiction, the Constitution makes those decisions itself. In his view, "The judicial power shall extend to" means "The jurisdiction of the federal courts must include." 13

Among the objections to Clinton's thesis is that it would fill the federal courts with diversity cases. Shortly after Clinton's first article appeared, Akhil Amar sought to save the mandatory theory from itself by developing a version that would avoid such a result. ${ }^{14}$ Amar agrees with Clinton that the Vesting Clause is an order to Congress that it do something, and that the beginning of Section 2 may properly be paraphrased as "The jurisdiction of some federal court must extend to . ..." ${ }^{15} \mathrm{He}$ keeps the diversity floodgates closed, however, by picking up on a hint from Justice Story; Amar maintains that there are two tiers of Article III jurisdiction, one mandatory, the other permissive. He uses the word "all" as a mandatory-jurisdiction detector, noting that the first three heads of jurisdiction in Section 2 of Article III are described to include "all cases," while the others include only "controversies."16

According to Amar, when "all" appears three times and then disappears, its subsequent absence is freighted with meaning. The fact that "all" is missing tells the perceptive reader that the contrary of "all" is actually there, even though that contrary is not expressed. In this context, the contrary of "all" is "some." So we move from ( 1 ) "all cases . . . all cases . . . all cases . . . contro-

without a violation of its duty, have refused to carry it into operation. The judicial power of the United States shall be vested (not may be vested) in one supreme court, and in such inferior courts as congress may, from time to time, ordain and establish. Could congress have lawfully refused to create the supreme court, or to vest in it the constitutional jurisdiction? ... The judicial power must, therefore, be vested in some court, by congress; and to suppose that it was not an obligation binding on them, but might, at their pleasure, be omited or declined, is to suppose that, under the sanction of the constitution, they might defeat the constitution itself; a construction which would lead to such a result cannot be sound.

Id at 328-29 (emphasis added to "may"). The foregoing was dictum.

${ }^{13}$ See Clinton, 132 U Pa L Rev at 753-54 (cited in note 10).

" See Akhil Reed Amar, A Neo-Federalist View of Article III: Separating the Two Tiers of Federal Jurisdiction, 65 BU L Rev 205 (1985). Amar has since elaborated his position and defended it against critics. See Akhil Reed Amar, Marbury, Section 13, and the Original Jurisdiction of the Supreme Court, 56 U Chi L Rev 443 (1989); Akhil Reed Amar, The Two-Tiered Structure of the Judiciary Act of 1789, 138 U Pa L Rev 1499 (1990); Akhil Reed Amar, Reports of My Death Are Greatly Exaggerated: A Reply, 138 U Pa L Rev 1651 (1990).

${ }^{15}$ Amar, 65 BU L Rev at 231-32, 239 (cited in note 14).

${ }^{16}$ Id at $240-41$. 
versies . . . controversies," to (2) "all cases . . a all cases . . . all cases . . . [not-all] controversies . . [ [not-all] controversies," to (3) "all cases . . . all cases . . . all cases . . . [some] controversies . . . [some] controversies." The Extending Clause thus means that the jurisdiction of some federal court must include all the cases mentioned and some of each of the kinds of controversies. ${ }^{17}$

Following his textualism to its logical conclusion, Amar says that some federal court must have jurisdiction over at least two lawsuits in each of the controversy-denominated heads of jurisdiction. ${ }^{18}$ To the complaint that his interpretation makes Article III a piece of secret writing, comprehensible only with magnifying glass, Rosetta Stone, and a powerful imagination, Amar rejoins that his approach makes sense of every word. He can account for the presence and absence of the word "all" in a way that orthodox readings cannot. It takes a reading of the text, Amar maintains, to beat a reading of the text. ${ }^{19}$

This Article presents the reading he invites. It complements an earlier critique of Amar's position by Daniel Meltzer. ${ }^{20}$ Meltzer focuses especially on the Federal Convention and the first Congress and takes issue with Amar's historical claims concerning the understanding of Article III around the time of the framing. $\mathrm{He}$ also deals briefly with the textual problem, questioning the premise that an extension of the judicial power is the same thing as an extension of jurisdiction and suggesting that the switch from "all cases" to "controversies" may reflect a usage according to which controversies included only civil suits while cases included all legal proceedings. ${ }^{21}$ This Article develops and supports those possibilities in greater detail and provides a close textual criticism of the mandatory reading of the Extending Clause as well as of Amar's division between mandatory and permissive tiers of jurisdictional categories.

I then discuss the constitutional structure-the sum of all the texts-to which Amar also appeals. It is true that the federal courts are an independent branch of the national government and that the tenure of federal judges is different from that of judges in many States. From that, however, we can infer nothing about the extent to which the Constitution authorizes Congress

${ }^{17}$ See id at 242; Amar, $138 \mathrm{U}$ Pa L Rev at 1652 (cited in note 14).

${ }^{18}$ Amar, $138 \mathrm{U} \mathrm{Pa}$ L Rev at 1652-53 (cited in note 14).

${ }^{19}$ See id at 1655-56.

${ }^{20}$ Daniel J. Meltzer, The History and Structure of Article III, 138 U Pa L Rev 1569 (1990).

${ }^{21}$ Id at 1573-74 n 14 (discussing Vesting and Extending Clauses); id at 1575-76 (Cases include criminal prosecutions; controversies do not.). 
to limit federal jurisdiction. General principles, including those reflected in the constitutional structure, do not answer specific design questions. ${ }^{22}$

\section{ARTICLE III}

Before counting leaves on the trees I will sketch the forest. According to the traditional understanding of Article III, Congress enjoys substantial power over the jurisdiction of the federal courts. Its authority over the inferior federal courts is, considered in itself, as plenary as the commerce power. Congress may give them all the jurisdiction the Constitution permits, or none at all, or anything in between, as far as Article III is concerned. Other constitutional limitations, when applicable, restrict that power as they may restrict any power of Congress. As for the Supreme Court, Congress may not add to or subtract from its original jurisdiction, although it may, within the limits of Article III, create concurrent jurisdiction in the inferior federal courts. The congressional power to make exceptions from the Court's appellate jurisdiction is, in itself, limited only insofar as some limitations might be so large as no longer to constitute exceptions. Once again, the exceptions power is subject to any external constitutional limitations that may apply.

Here is the reading of the text that leads to that conclusion. Article III proceeds in three steps, in descending order of generality. Section 1 begins with the Vesting Clause. It provides that

\footnotetext{
22 This paper deals with Article III and does not discuss two issues that often come up in this context. First, I do not consider the interaction between Congress's exceptions power and the various constitutional limitations, such as the First Amendment. In Gerald Gunther's terminology, this piece deals only with internal and not with external restraints on congressional power. See Gerald Gunther, Congressional Power to Curtail Federal Court Jurisdiction: An Opinionated Guide to the Ongoing Debate, 36 Stan L Rev 895,900 (1984).

Second, I do not consider the thesis that certain government actions, especially deprivations of life, liberty, or property, must be accomplished through judicial, rather than executive or legislative, power. This principle, which may derive either from the separation of powers or from the Due Process Clause, see Murray's Lessee $v$ Hoboken Land \& Improvement Co, 59 US (18 How) 272, 275, 280-81 (1855) (While "due process of law" usually requires that judicial proceedings be conducted by judicial officers, there are exceptions, such as the Treasury Department's seizure of a delinquent tax collector's property.), may limit Congress's power to "preclude judicial review" of executive actions-that is, to provide that the executive may engage in certain activity and that no court shall have jurisdiction to give a remedy for what the executive has done, see Webster $v$ Doe, 486 US 592, 601-05 (1988) (holding that Congress did not intend to preclude judicial review of constitutional claims based on termination of employment with the Central Intelligence Agency-any such intent must be clear, since it would raise a "serious constitutional question"). Such questions are separate from those concerning Congress's power over federal jurisdiction per se.
} 
there is to be a single highest federal court, as there is to be a single President, and that there may or may not be lower federal courts, as Congress decides. Whatever federal courts there are have the power to decide cases and controversies for the national government because they have the judicial power, just as the President has the executive power. The tenure and salary provision, which applies to all federal judges, sets their term of office and limits Congress's power over their compensation.

Section 1 is quite abstract, so abstract that it does not even tell us which lawsuits the federal judiciary may decide. The Extending Clause, the first paragraph of Section 2, answers that question. It does so with respect to both the Supreme Court and the inferior courts, because it speaks of the extent of the judicial power, which the Constitution vests in both. The clause provides a list of lawsuits that may be decided by federal courts. It thus performs a vital function in a constitution of enumerated powers by setting out the maximum level of federal judicial authority. Part of the way through, the clause switches from enumerating "all cases" to enumerating "controversies." Cases include all legal actions, criminal and civil, while controversies include only civil proceedings. The word "all" appears before "cases" for two reasons. First, it stresses both the comprehensive reach of "cases" and the restricted reach of "controversies." Second, it confirms the breadth of the national judicial authority in the new federal system, indicating that under the case-denominated heads of jurisdiction the federal courts may take the seemingly unusual step of adjudicating state criminal proceedings.

The level of abstraction so far is still fairly high because we do not know anything about the actual jurisdiction of any court. The second paragraph of Section 2 addresses jurisdiction, in part explicitly and in part implicitly. It explicitly sets out the original jurisdiction of the Supreme Court, which Congress is nowhere given power to change. It also sets out the Court's appellate jurisdiction, which is comprehensive but subject to a congressional power to make exceptions. Section 2 says nothing about the jurisdiction of the inferior federal courts. All we know is that Congress is free to constitute such of them as it sees fit. The inference is that their jurisdiction, within the scope of the federal judicial power, is to be determined when Congress exercises that authority. The result is that the actual sweep of federal jurisdiction is, like many other questions under the Constitution, subject to substantial congressional discretion.

Now for the trees and leaves. 


\section{A. The Vesting Clause}

The Vesting Clause of Article III lays down a number of rules. Most important are those that help to establish the separation of powers. By providing that the federal judicial power be held by the courts of the United States, it implies that no other institution of government, whether established by the Constitution, by Congress pursuant to the Constitution, or by a State, may exercise that power. It also authorizes the federal courts to exercise the judicial power; as we learn in Section 2, these courts are to do so by deciding cases and controversies. Moreover, the clause implies that there is to be a supreme court and provides that there is to be only one such institution.

The Vesting Clause is a self-executing enactment; it lays down rules by saying what shall be. It is equivalent to "The judicial power of the United States is hereby vested in one supreme court ...."23 Contrary to the mandatory theories, however, the Vesting Clause of Article III is not a command that Congress vest power in the courts. This appears from an examination of the parallel clause of Article I, which provides, "All legislative Powers herein granted shall be vested in a Congress of the United States." That is not a command that Congress vest itself with power, unless we are to believe that the legislature is capable of lifting itself by its bootstraps, giving itself power before it has power to do anything, including give itself power.

Moreover, whatever might be the extent of Congress's power with respect to the inferior courts, an examination of the text belies the claim that Congress could vest the judicial power in the Supreme Court. The text grants Congress no power that applies specifically to the Court other than the authority to except from and regulate its appellate jurisdiction. Indeed, the only provision that might implicitly give Congress any authority with respect to the Court confirms that the Constitution, not Congress, vests the judicial power in the highest tribunal. This provision is the Necessary and Proper Clause, which authorizes the national legislature to make laws "for carrying into Execution [its own enumerated powers], and all other Powers vested by this Constitution in the Government of the United States, or in any Department or Officer thereof." ${ }^{24}$ The only laws Congress may pass with respect to the Court pursuant to this authorization are those that carry

\footnotetext{
${ }^{2}$ It has the same structure as Section 1 of the Twenty-First Amendment, which provides "The eighteenth article of amendment to the Constitution of the United States is hereby repealed." This is also the structure of the Preamble.

${ }^{24}$ US Const, Art I, \$ 8, cl 18.
} 
into execution powers already vested in the Court by the Constitution. Although Congress does indeed pass such laws, for example, when it establishes the office of Clerk and provides a building, it is hard to see how a law purporting to give the Court the judicial power in the first place could be said to carry into execution any power the institution already had.

Despite Justice Story's histrionics, ${ }^{25}$ the suggestion that Article III begins with a command to Congress to vest the judicial power cannot be sustained. The rules laid down by the Vesting Clause are mandatory, to be sure, in that the legislature has no power to change them. The clause does not, however, order Congress to do the vesting. The Constitution does that itself. ${ }^{26}$

\section{B. The Extending Clause}

Here the issue is really joined. Orthodoxy maintains that the first paragraph of Section 2 sets out the maximum scope of the jurisdiction of the federal courts without determining the extent to which any federal court shall actually have any or all of that jurisdiction. A traditionalist paraphrase of the clause, then, would begin, "The judicial power may be used to decide . . ." or "The judicial power shall be capable of deciding ...." Mandatory theory, by contrast, maintains that the clause sets out both the maximum and minimum jurisdiction of the federal courts. ${ }^{27}$ It is, as we shall see, more difficult to come up with a good paraphrase of the mandatory reading.

Article III, which charters the judiciary of a government of enumerated powers, must address two issues. First, it must determine the maximum scope of federal jurisdiction. This is a fundamental matter, as the principle of enumerated powers pervades the document. It appears in the first sentence of Article I, which vests in Congress all the legislative powers "herein granted," and is made explicit in the capstone of the framing settlement, what is now the Tenth Amendment. As a consequence, one of the basic questions that the structural provisions of the

\footnotetext{
$\approx$ See note 12

${ }^{26}$ Steven Calabresi has pointed out that the Vesting Clause of Article III is the provision of the Constitution that authorizes the federal courts to exercise power. See Steven G. Calabresi, The Vesting Clauses As Power Grants, 88 Nw U L Rev 1377, 1380-89 (1994).

${ }^{27}$ According to Clinton, the maximum and minimum coincide, so the clause lists the categories of cases that must be within the jurisdiction of some federal court. See Clinton, $132 \mathrm{U} \mathrm{Pa}$ L Rev at 753 (cited in note 10). According to Amar, they coincide for the casedenominated heads of jurisdiction but not for the others, so the former prescribe the categories of cases that must be within the jurisdiction of some federal court while the latter demand that at least two controversies from each category be finally determinable by a court of the United States. See Amar, 65 BU L Rev at 240 \& n 119 (cited in note 14).
} 
Constitution must answer concerns the maximum reach of federal authority, the most that might be done by the new government. That question is conceptually separate from the question of the extent to which that authority actually will be exercised. To say what kinds of laws may be passed is not to say whether they will be passed; to grant a power is not to determine how far it will be used.

The Constitution, therefore, also must deal with the question of the extent to which federal judicial authority actually will be exercised. It need not, to be sure, resolve that question. Instead, the decision can be left for Congress, as many important choices are. In fact, orthodox and mandatory theorists agree that the Constitution itself partly determines the actual jurisdiction of the federal courts while leaving some discretion to Congress. According to the orthodox reading, the Constitution fixes the original jurisdiction of the Supreme Court and sets a default for the Court's appellate jurisdiction while giving Congress power to make exceptions; inferior court jurisdiction is for Congress to set, up to the constitutional maximum. Clinton, by contrast, argues that the Constitution fixes the set of cases and controversies that must be open to decision by a federal court while leaving to Congress some discretion to allocate cases between the Supreme Court and whatever inferior courts Congress chooses to create. ${ }^{28}$

Orthodoxy maintains that the Extending Clause resolves the first issue and does only that. In setting out the extent of the federal judicial power, according to this reading, the Constitution sets the maximum potential reach of the federal courts' power to decide cases and controversies. Their actual jurisdiction is dealt with in the provisions that refer to particular courts. Those provisions are the second paragraph of Article III, Section 2, which deals with the Supreme Court's jurisdiction, and the passages in Articles I and III that authorize Congress to constitute inferior tribunals. ${ }^{29}$

It is sensible to read the Extending Clause as setting out the maximum potential scope of federal jurisdiction for two reasons. First, as a general matter, a reference to the extent of a governmental power is a natural way to set out the power's maximum potential use. This point appears if we consider what it means in

\footnotetext{
Amar combines the two theories, suggesting Clinton's result is correct for the casedenominated heads of jurisdiction while the orthodox reading is proper for the controversy-denominated heads, subject to the proviso that "some" of each of the enumerated controversies must be eligible for federal decision. See Amar, 65 BU L Rev at 240-46 (cited in note 14).

${ }^{\star}$ See US Const, Art I, § 8, cl 9; Art III, § 1.
} 
other constitutional contexts to speak of the extent of a power. To describe the extent of Congress's power, for example, is to describe the ways in which the power might be exercised. It is to speak of a potential, and not of the power's actual use. This locution is not novel. In Ogden $v$ Saunders, Justice Washington referred to the areas in which Congress had been given power as "every other subject to which the power of Congress had been previously extended." ${ }^{\prime 30}$ The power of Congress extends to passing a law that would make the erg the country's official unit of measure for energy. ${ }^{31}$ As far as I can tell, however, that power has never been exercised..$^{32}$ Congressional power extends to the passage of many laws that have not been and probably never will be enacted. To describe the extent of legislative power is to describe the laws that may be passed, to describe the potential applications of that power. Moreover, to prescribe the full extent of a power is to set out its maximum potential reach. Describing the legislative power's extent, however, is not to say which of the permissible laws shall be passed. A description of extent leaves that question for another day.

It is easy to see the parallel formulation with respect to the judicial power. Under an analogous reading, a provision setting out the extent of the judicial power would set out the most that might be done with the power without deciding whether it would be done. Before any case actually could be decided, someone would have to take a second step. An examination of Article III shows that the second step concerning jurisdiction is partly taken by the Constitution itself and partly left to Congress: the Constitution sets out rules concerning the jurisdiction of the Supreme Court, while giving Congress some power to alter that jurisdiction and full power over the jurisdiction of the inferior courts, within the limits to which the judicial power extends.

Second, Article III's shift in Section 2 from the judicial power (its vesting and its extent) to the jurisdiction of a specific tribunal is a natural way of expressing separate answers to the separate questions of the maximum scope of the lawsuits federal courts may be able to decide and the actual rules that determine the lawsuits they will be able to decide at any time. Judicial power and jurisdiction are obviously closely related concepts, but, just as obviously, they are not the same concept. According to the Constitution's usage, the Supreme Court and the inferior federal

\footnotetext{
${ }^{30} 25$ US (12 Wheat) 213, 275 (1827).

${ }^{31}$ See US Const, Art I, § 8, cl 5 (weights and measures).

${ }^{32}$ The official units of measure for energy are the joule and the kilowatt-hour. 15 USC $\S 223$ (1994).
} 
courts have the same judicial power-they are vested with the judicial power of the United States-even though they have different jurisdictions. ${ }^{33}$ The judicial power is thus less specific than a particular court's jurisdiction, as the potential is less specific than the actual.

The orthodox interpretation, then, accounts for Article III's two-stage formulation. It also raises the question of why, given that the working business of government requires provision for the jurisdiction of actual courts, the framers proceeded in two stages. Article III's formulation is not the only way to put the point, and it may seem needlessly complex. Why not talk about jurisdiction throughout? The answer is that the two-stage process, moving from judicial power to jurisdiction, is a relatively clear and elegant way of accommodating the compromise that put off the question of whether to have inferior federal courts. This point comes into sharp focus if we compare the two-stage approach with the alternative way of accomplishing the same result, which would drop the stage dealing with the judicial power in the abstract and address only the jurisdiction of courts.

It is especially easy to make this comparison because the drafting process of Article III provides the contrast. The judiciary article reported by the Committee of Detail did not use the intermediate stage about the judicial power. ${ }^{34}$ The problem with

${ }^{33}$ State constitutions from the time of the framing and shortly thereafter also use this phrasing, whereby courts with differing jurisdictions are all vested with the same judicial power. Examples include the Delaware Constitution of 1792, Art VI, $\$ 1$ (judicial power of the State vested in a court of chancery, a supreme court, courts of oyer and terminer and general gaol-delivery, a court of common pleas, and various others); the Georgia Constitution of 1798, Art III, $\S 1$ (judicial power vested in superior court and such inferior courts as the legislature shall establish; jurisdiction of superior court then set out); the Kentucky Constitution of 1792 , Art V, $\$ \S 1,3$ (judicial power vested in one supreme court and such inferior courts as the legislature may ordain and establish; jurisdiction of supreme court set out); and the Pennsylvania Constitution of 1790 , Art V, $\$ 1$ (judicial power vested in listed courts, including such others as the legislature may establish). lows:

${ }^{37}$ After a vesting clause and a tenure clause, the Committee's report provided as fol-

The Jurisdiction of the Supreme Court shall extend to all cases arising under laws passed by the Legislature of the United States; to all cases affecting Ambassadors, other Public Ministers and Consuls; to the trial of impeachments of Officers of the United States; to all cases of Admiralty and maritime jurisdiction; to controversies between two or more States, (except such as shall regard Territory or Jurisdiction) between a State and Citizens of another State, between Citizens of different States, and between a State or the Citizens thereof and foreign States, citizens or subjects. In cases of impeachment, cases affecting Ambassadors, other Public Ministers and Consuls, and those in which a State shall be party, this jurisdiction shall be original. In all the other cases before mentioned, it shall be appellate, with such exceptions and under such regulations as the Legislature shall make. The Legislature may assign any part of the jurisdiction above mentioned (except the trial of the President of the United States) in the manner, and under the limitations which it shall think 
that approach is that the appearance of the inferior courts comes as a surprise. All along the reader has been led to believe that the provision deals with the jurisdiction of the Supreme Court; that is natural enough, because only the Supreme Court is certain to exist. Then it turns out the provision has also been setting out the potential jurisdiction of the inferior courts, should there be any. Article III, by contrast, associates the jurisdictional heads with the more abstract judicial power of the United States, which it has just told us is vested in the supreme and inferior courts. Thus the reader knows all along that the list applies to the federal courts generally, with it understood that it is up to Congress whether there will be any inferior courts. Moreover, the approach the Convention finally adopted (and that the Committee of Style polished) is more elegant because it dispenses with the need to mention the inferior courts. We know all that we need to know from the Extending Clause and from Congress's power to constitute those tribunals. Thus does the orthodox reading explain the move from judicial power to jurisdiction.

Clinton's mandatory theory, by contrast, is hard pressed to explain the language of Article III. He maintains that the Extending Clause, in addition to whatever else it does, deals with the actual jurisdiction of the federal courts by setting a floor on their collective authority: some federal court must be able to decide all the enumerated cases and controversies. This reading encounters severe difficulties. It tries to combine multiple functions in a single clause in a way that is at best cumbersome and, worse yet, very difficult to squeeze out of the text.

One problem is gross inelegance. Mandatory theorists and traditionalists agree that if Congress were simply to set the number of Supreme Court judges and not use its exceptions power, all would be right with the world: the Court would have jurisdiction over all cases and controversies eligible for federal resolution. Under such circumstances, one would not need to know whether there is a floor on federal jurisdiction. That question can arise only if Congress exercises its power to except from the Court's appellate jurisdiction. It is then that the floor-setting function of Clinton's Extending Clause kicks in: if Congress excepts any cases from the appellate jurisdiction, it must create

proper, to such Inferior Courts, as it shall constitute from time to time.

Max Farrand, ed, 2 The Records of the Federal Convention of 1787 186-87 (Yale rev ed 1966). On August 27 the Convention replaced "The Jurisdiction of the Supreme Court" with "the Judicial power," and deleted the sentence beginning "The Legislature may assign." Both votes were unanimous. Id at 431. 
federal jurisdiction over those cases elsewhere, by an exercise of its power to constitute inferior tribunals.

Clinton's Extending Clause, although it does not say so, is thus a condition on the exceptions power, one that requires an exercise of the inferior-tribunals power. The rest of the Constitution is not drafted in this indirect and allusive manner; it is drafted more sensibly. Limitations on congressional power are phrased as such. A limitation on a specific power is usually attached to the power itself: duties, imposts, and excises, like laws on bankruptcy and naturalization, must be uniform; the power to raise and support armies has joined to it the proviso that no appropriation for an army be for more than two years. ${ }^{35}$ Similarly, affirmative duties, which are rare, are phrased as such. The census is required to be taken and the President is enjoined to take care that the laws be faithfully executed..$^{36}$

Even if we are prepared to believe that the Extending Clause plays hide-and-seek, it is not clear how Clinton thinks it does so. How would we paraphrase the clause so that it does what his theory needs it to do? Clinton's suggestion seems to be this: it means, "The jurisdiction of some federal court must extend to ...."The fact that the Constitution nowhere uses the word "must" suggests that something strange is afoot, as indeed it is. A translation of "shall" as "must" appeals to Clinton because it sets a floor. If some federal court must be able to decide a case, surely some federal court may be able to do so. But what about the ceiling? As explained above, to set the extent of a power is to set limits on that power. But to say what cases jurisdiction must reach implies no such limits. If the Extending Clause sets no ceiling, the sky is the limit. Congress has explicit power to constitute tribunals inferior to the Supreme Court, tribunals possessing the judicial power of the United States. In establishing an in. ferior tribunal, it is necessary and proper to give it jurisdictionsay, jurisdiction over all cases between citizens of the same State. ${ }^{37}$ So much for enumerated judicial power.

$\approx$ US Const, Art I, $\$ 8$, cl 1 (granting power to "lay Duties, Imposts, and Excises," but requiring that they be uniform); id, cl 4 (granting power to "establish an uniform Rule of Naturalization, and uniform Laws on the subject of Bankruptcies throughout the United States"); id, cl 12 (granting power to "raise and support Armies, but no Appropriation of Money to that Use shall be for a longer Term than two Years").

${ }^{36}$ US Const, Art I, § 2, cl 3 (census "shall be made"); id, Art II, § 3 (President "shall take Care that the Laws be faithfully executed").

${ }^{37}$ If leaving these inferior courts without appellate supervision sounds like creating multiple supreme courts, never fear. Giving the real Supreme Court appellate jurisdiction over these cases would be a proper way to ensure that the inferior courts perform their function well. 
If "must" does not work, we can go back to "shall." Clinton's key move is to equate the judicial power of the United States with the jurisdiction of the federal courts, so that jurisdiction may simply be substituted in sentences referring to judicial power. I suggest above that this is an odd move, because the phrases are different and can readily be seen to name two closely related, but nevertheless distinct, items of constitutional furniture: the potential and the actual scope of federal jurisdiction. Suppose nevertheless that the Extending Clause can be translated as, "The jurisdiction of the federal courts is hereby extended to ...." That is the natural paraphrase of the Extending Clause if Clinton is right that the judicial power is identical with the jurisdiction of the federal courts. ${ }^{38}$ Such a provision may provide the necessary ceiling, but now there is a problem with the floor. ${ }^{39}$ The statement that jurisdiction is extended to certain cases, combined with the later statement that Congress may except from jurisdiction, implies that the Constitution enacts an initial rule that Congress then may modify. ${ }^{40}$ That is not the mandatory reading.

Amar proposes a modified form of Clinton's interpretation, one designed to keep the diversity jurisdiction under control. As William Casto has pointed out, Amar's all/some reading produces nonsense when combined with Clinton's mandatory reading. ${ }^{41}$ Clinton maintains that a reference to the extent of the judicial power authorizes the exercise of jurisdiction, sets a ceiling on actual jurisdiction, and sets a floor on actual jurisdiction: "The judicial power shall extend to ..." means "The jurisdiction of the federal courts must extend to, and may only extend to ....."

\footnotetext{
${ }^{3}$ On the orthodox reading, because the phrases are not interchangeable, otherwisesimilar statements using them are related but not identical. To say that the judicial power extends to a case is to say that the jurisdiction of some federal court may do so.

${ }^{3}$ In fact, there are still problems with the ceiling. If the Extending Clause does mean that the jurisdiction of the federal courts is extended to certain cases and controversies, the mandatory reading needs an implicit "only" to set the maximum. Otherwise Congress, through its power to constitute inferior tribunals, once again can add more federal jurisdiction. This is not a problem for the orthodox reading, which takes seriously the fact that the Extending Clause refers, not to the jurisdiction of the federal courts, but to the judicial power. In a constitution of enumerated powers, one in which the "powers not delegated to the United States . . . are reserved to the States respectively, or to the people," US Const, Amend X, grants of power are implicitly limiting.

${ }^{40}$ This is the procedure the Constitution adopts with respect to the date of Congress's annual meeting. US Const, Amend XX, $\S 2$.

"See William R. Casto, An Orthodox View of the Two-Tier Analysis of Congressional Control Over Federal Jurisdiction, 7 Const Comm 89, 90-91 (1990). Casto's discussion of the two-tier thesis in the context of the mandatory reading accepts the premise that the absence of "all" implies the presence of "some." I contend below that this inference is unsound.
} 
Amar maintains that the absence of "all" implies the presence of "some" before "controversies." If these two paraphrases are put together, then as to the controversy-denominated heads, the Extending Clause means "The jurisdiction of the federal courts must extend to, and may extend only to ... some controversies ...." Amar's reading focuses on the "must" part, but the mandatory reading has to contain not only "must" but also "may only." If the mandatory theory is correct, the maximum scope of federal court jurisdiction as to controversies-the "may only" part-includes the modifier "some." The jurisdiction of the federal courts may not include, for example, all controversies to which the United States is a party, because it may include only some of those controversies. At least two must be left out, whatever that means exactly. This is a very strange place to put the ceiling.

Casto's critique assumes that [no-all] means "some but not all," or "only some."43 That seems reasonable enough, given that the two-tier theory interpolates a word or phrase that takes its meaning by a contrast with "all," the absence of "all" being the signal that the word or phrase needs to be interpolated. Perhaps the two-tier reading can be salvaged if [no-all] means "at least some." This solution is highly implausible, however. First, if much is to be read into the absence of "all," the natural reading is indeed the strongest contrary of "all," which is "some but not all." Second, by introducing this refinement, two-tier theory now finds in silence not simply sound but an elaborate fugue: [no-all] means something quite precise and must not mean anything else. Finally, it is still not clear that the reading makes any sense. "The jurisdiction of the federal courts may extend only to at least some controversies . . ." is so unnatural as to be at most barely meaningful.

All this trouble with the two-tier reading arises because that interpretation really needs two Extending Clauses for the controversy-denominated tier. One clause would authorize jurisdiction and set out its maximum scope. That Extending Clause rejects both Clinton's reading and Amar's: it would use “The judicial power shall extend to ..." to mean, "The judicial power may be used to decide, and only to decide . . .," which is the orthodox reading, and would assume that "Controversies" refers to every one of the lawsuits described, not just some or at least some of

\footnotetext{
"This discussion of Amar assumes what I think is false, that the Extending Clause somehow can generate both the maximum and the minimum rules Clinton attributes to it.

* See Casto, 7 Const Comm at 91 (cited in note 41).
} 
them. The other Extending Clause would establish the floor for federal jurisdiction. It would embrace Clinton's understanding of "The judicial power shall extend to ..." and Amar's understanding of the absence of "all." But there is only one Extending Clause.

On the orthodox reading the Extending Clause is natural, indeed elegant. On either mandatory reading it is obscure at best, more likely unintelligible.

\section{The Change From "All Cases" to "Controversies": Two Tiers of Jurisdiction}

Neither Amar nor Clinton, then, can explain how the language of the Extending Clause does what they think it does. Amar, however, is correct in puzzling over the fact that in the midst of laying out the lawsuits to which the federal judicial power extends, the clause switches terminology. The power extends to all cases arising under federal law, to all cases affecting ambassadors, other public ministers and consuls, and to all cases of admiralty or maritime jurisdiction. It further extends to controversies-not all cases, not cases, not all controversies-to which the United States shall be a party, and so forth. Perhaps Article III is trying to mystify us-why the change from all cases to controversies? Amar suggests that this change signals a switch from lawsuits that must be heard in some federal court to those that may be if Congress so decides.

The language of the Extending Clause does indeed demarcate two tiers of federal judicial power, but the difference is not between required and permitted jurisdiction. Rather, it is about the scope of the different jurisdictional heads. "All cases" includes both civil lawsuits and criminal prosecutions by American governments, state and federal. The word "all" emphasizes that "cases" is a general term encompassing both civil and criminal proceedings. It also indicates that the Constitution sometimes authorizes federal courts to entertain criminal prosecutions under state law. The Constitution thus partially rejects the principle that the courts of one sovereign will not enforce the criminal laws of another, if one sees the state and federal governments as different sovereignties. It would probably be more accurate to say that the Constitution structures the state and federal governments so that in them sovereignty is partially divided and partially integrated. The result of this unique arrangement is that state and federal courts are not foreign to one another for all purposes. "Controversies," however, includes only civil proceedings; the heads of jurisdiction so denominated include some in 
which it would be inappropriate to entertain state criminal prosecutions in federal court.

In this section I will first develop the two-tiered view just described. I will then discuss the textual objections to Amar's explanation of the shift from "all cases" to "controversies."

1. "All" cases: civil and criminal, federal and state.

a) Cases and controversies, civil and criminal proceedings. Recent scholarship has noted that two respectable authorities from the early days of the Constitution addressed the terminology used in Article III. ${ }^{44}$ Justice James Iredell, one of President Washington's first appointees to the Supreme Court, and St. George Tucker, a Virginia judge and annotator of Blackstone, both asserted that the term "controversies" includes only civil proceedings. ${ }^{45}$ I have two points to add. First, there is additional evidence that confirms what Iredell and Tucker said, although it does not conclude the point. Second, I wish to emphasize the connection between the limited scope of "controversies" and the principle, familiar then and now, that the courts of one sovereign will not enforce the penal laws of another.

The development of the use of "controversy" to refer specifically to civil proceedings remains somewhat hazy. English legal dictionaries available in America in the late eighteenth century that I have found do not have a separate definition for

" See William A. Fletcher, Letter to the Editor, in Exchange on the Eleventh Amendment, 57 U Chi L Rev 131, 133 (1990); James E. Pfander, Rethinking the Supreme Court's Original Jurisdiction in State-Party Cases, 82 Cal L Rev 555, 604-09 (1994).

* Dissenting in Chisholm $v$ Georgia, 2 US (2 Dall) 419 (1793), Justice Iredell said this about the state-party jurisdiction over controversies:

The constitution is particular in expressing the parties who may be the objects of the jurisdiction in any of these cases, but in respect to the subject-matter upon which such jurisdiction is to be exercised, used the word "controversies" only. The act of Congress [the Judiciary Act of $1789 \$ 13, \operatorname{ch} 20,1$ Stat 73,80 ] more particularly mentions civil controversies, a qualification of the general word in the constitution, which I do not doubt every reasonable man will think well warranted, for it cannot be presumed, that the general word "controversies" was intended to include any proceedings that relate to criminal cases, which in all instances that respect the same government only, are uniformly considered of a local nature; and to be decided by its particular laws. The word "controversy" indeed, would not naturally justify any such construction, but nevertheless it was perhaps a proper instance of caution in congress to guard against the possibility of it.

Id at 430-31. Judge Tucker glossed the first appearance in Article III of "controversies" thus: "The word controversies, as here used, must be understood merely as relating to such as are of a civil nature. It is probably unknown in any other sense, as I do not recollect ever to have heard the expression, criminal controversy." St. George Tucker, ed, 1 Blackstone's Commentaries App at 420 (Birch and Small 1803). 
"controversy." American legal dictionaries in the nineteenth century, however, regularly define "controversy" as a civil case. ${ }^{47}$ Story, in his Commentaries on the Constitution, cited Tucker's and Iredell's construction of the term without either endorsing or rejecting their reading. ${ }^{48}$

It is not possible at this point to say with confidence what happened, or to assess fully the extent to which Iredell and Tucker were correct. Perhaps they first articulated an Americanism that was in the process of becoming a term of art, one that eventually made its way into dictionaries. Or they may have been more involved in the causal process than that; perhaps the term took on the limited meaning, and began to appear under that usage in dictionaries, because these two important authorities said it had that meaning. Most of the evidence so far, however, supports the conclusion that Iredell and Tucker helped a meaning crystallize, rather than drawing one out of thin air. There is reason to believe that at the time of the framing, the

${ }^{\star 6}$ See Thomas Blount, A Law-Dictionary and Glossary (Eliz, Nutt \& Gosling 3d ed 1717); John Cowel, A Law Dictionary (Nutt \& Gosling 2d ed 1727); Timothy Cunningham, $1 \mathrm{~A}$ New and Complete Law-Dictionary (Law-Printers to the King 1764); Giles Jacob, $A$ New Law-Dictionary (Lintot 5th ed 1744). For bibliographies of legal works from this period, including law dictionaries, see William $\mathrm{H}$. Bryson, Census of Law Books in Colonial Virginia (Virginia 1978); Herbert A. Johnson, Imported Eighteenth-Century Law Treatises In American Libraries, 1700-1799 (Tennessee 1978).

${ }^{47}$ The earliest American dictionary I have been able to consult is the first edition of Bouvier's, from 1839; it does not contain a separate definition of "controversy." John Bouvier, 1 Law Dictionary (1st ed 1839). By the third edition in 1848, however, Bouvier defined a controversy as "a dispute arising between two or more persons; it differs from case, which includes all suits criminal as well as civil; whereas controversy is a civil and not a criminal proceeding." John Bouvier, I A Law Dictionary 337 (Johnson 3d ed 1848). Bouvier cited Iredell, Tucker, and Story. Id. The distinction was still around in 1883. See Stewart Rapalje and Robert L. Lawrence, 1 A Dictionary of American and English Law 286 ( Linn 1883) (defining controversy as a "dispute between two or more persons; a civil action or suit, either at law or in equity"). The suggestion that there were variant usages, however, can be found in an 1889 dictionary, which in large type defines "controversy" as "[a]ny issue, whether of a civil or criminal nature; a case," and then in small type says, "[a] civil proceeding; as, that the judicial power of the United States shall extend "to Controversies to which the United States shall be a Party." William C. Anderson, A Dictionary of Laiw 252 (Flood 1889). Anderson's entry on "Cases and controversies" cites Justice Field for the proposition that "controversies,' if distinguishable from 'cases,' is so in that it is less comprehensive than the latter, and includes only suits of a civil nature." Id at 153, citing In re Pacific Railway Commission, 32 F 241, 255 (1887). The first edition of Black's Law Dictionary, in 1891, says that "controversy" differs from "case,' which includes all suits, criminal as well as civil; whereas 'controversy' is a civil and not a criminal proceeding," and cites Iredell. Henry Campbell Black, Black's Law Dictionary 271 (1st ed 1891). In 1893, Kinney's A Law Dictionary and Glossary defined "controversy" as "[a] dispute; a civil action or proceeding." J. Kendrick Kinney, Law Dictionary and Glossary 197 (Callaghan 1893).

4 Joseph Story, 2 Commentaries on the Constitution of the United States $\$ 1674$ at 445 n 1 (Little, Brown 2d ed 1851). 
word "controversy," in a legal context, connoted a disagreement between jural equals, and in particular a dispute over private rights. The word "case," by contrast, seems to have applied more generally to include situations in which the courts, rather than arbitrating disputes, acted as organs for the application of public power. A criminal prosecution is the central example of the latter type of proceeding.

Some writings from the ratification debates strongly suggest that their authors equated controversies with civil proceedings. The New York anti-federalist who wrote as Brutus, for example, summarized Article III in these words: "The powers of [the proposed federal] courts are very extensive; their jurisdiction comprehends all civil causes, except such as arise between citizens of the same state; and it extends to all cases in law and equity arising under the constitution." ${ }^{49}$ Brutus's reference to the heads of jurisdiction that comprehend nearly all civil causes is almost certainly an epitome of the controversy-denominated heads.

Two other passages include revealing usages of "cases" and "controversies." During the Pennsylvania ratifying convention, Robert Whitehill, an anti-federalist, offered a set of amendments. One would have limited the judicial power

to cases affecting ambassadors, other public ministers and consuls, to cases of admiralty and maritime jurisdiction, to controversies to which the United States shall be a party, to controversies between two or more states-between citizens claiming lands under grants of different states, and between a state or the citizens thereof and foreign states, and in criminal cases, to such only as are expressly enumerated in the Constitution..$^{50}$

After referring several times to "controversies," when Whitehill wanted to speak of criminal proceedings he switched back to "cases." This shift suggests the words had contrasting meanings and that only "cases" included criminal proceedings.

Similarly, "A Native of Virginia" said this to defend the Constitution against the common charge that it eliminated civil jury trial:

${ }^{4}$ Brutus 1, in John P. Kaminski and Gaspare J. Saladino, eds, 13 The Documentary History of the Ratification of the Constitution 411, 415 (State Hist Socy Wis 1981). "Brutus" probably was New York judge Robert Yates. See G. Edward White, Recovering Coterminous Power Theory: The Lost Dimension of Marshall Court Sovereignty Cases, in Maeva Marcus, ed, Origins of the Federal Judiciary: Essays on the Judiciary Act of 1789 66, 103 n 33 (Oxford 1992).

"Merrill Jensen, ed, 2 The Documentary History of the Ratification of the Constitution 598-99 (Worzalla 1976). 
In criminal cases, the trial by jury is most important. In criminal cases the Constitution has established it unequivocally. But in having only recognized this trial in criminal, it by no means follows that it takes it away in civil cases: And we may fairly presume, that by the law which the Congress will make to compleat the system of the Federal Court, it will be introduced, as far as it shall be found practicable, and applicable to such controversies as from their nature are subjects proper to be determined in that Court. ${ }^{51}$

The Virginian's usage strongly suggests he equated controversies with civil cases.

Another important indicator that Iredell and Tucker were correct about the legal connotation of "controversies" is the fact that it was often used interchangeably with "disputes." The Federal Convention, drafting what became Article III, switched from "disputes" to "controversies" as if they were synonyms. ${ }^{52}$ At the Virginia ratifying convention a number of speakers did likewise. George Mason, for example, presented a detailed critique of the controversy-denominated heads in which he used one word and then the other, as if he were engaging in purely stylistic variation. ${ }^{53}$ Similar usage is found in speeches of Edmund Pendleton and Edmund Randolph. ${ }^{54}$ To speak of a dispute connotes a con-

${ }^{51}$ Observations upon the Proposed Plan of Federal Government, in John P. Kaminski and Gaspare J. Saladino, eds, 9 The Documentary History of the Ratification of the Constitution 655, 686 (State Hist Socy Wis 1990).

${ }^{52}$ Draft judiciary provisions used by the Committee of Detail, largely in the hand of Edmund Randolph, extended the jurisdiction of the supreme tribunal to "disputes between a State \& a Citizen or Citizens of another State," to "disputes between different states," and to "disputes, in which subjects or citizens of other countries are concerned." Farrand, 2 Records at 147 (cited in note 34). The next Committee of Detail draft that deals with this matter is much like Article III and uses "controversies" instead of "disputes." Id at 173.

${ }_{53}$ See John P. Kaminski and Gaspare J. Saladino, eds, 10 The Documentary History of the Ratification of the Constitution 1403 (State Hist Socy Wis 1993).

${ }^{54}$ Id at 1427 (Pendleton) (discussing disputes); id at 1451 (Randolph) (referring to both "disputes" and "controversies" between states). Madison referred to the federal courts' "cognizance of disputes between citizens of different States." Id at 1414. The Virginia ratifying convention's proposed amendments to Article III likewise used "disputes" as a synonym for "controversies," id at 1555, as did the Pennsylvanian called "One of the People," Letter, To the Freemen of Pennsylvania, in Jensen, ed, 2 Documentary History at 186, 191 (cited in note 50).

Examples can be multiplied. Thomas Sergeant, for instance, began a paragraph about colonial jurisdiction by stating, "Controversies between two of the provinces concerning the extent of their charter boundaries or the like, came before the King in his privy council," Thomas Sergeant, A Brief Sketch of the National Judiciary Powers Exercised in the United States, in Peter S. DuPonceau, A Dissertation on the Nature and Extent of the Jurisdiction of the Courts of the United States 135, 140 (Arno 1972) (reprinting 1824 ed), and continued, "Thus in July 1764, the King in privy council approved the report of a committee of council for plantation affairs, relative to the disputes that had for some 
test between equals, like two claimants to the same property..$^{55}$ It does not fit well with a criminal proceeding, in which the power of the government is brought to bear against an individual through the courts. ${ }^{56}$

Speeches by the two Edmunds of Virginia (Pendleton and Randolph) provide further support for the claim that controversies means civil cases. During the ratifying convention, each of them referred to "criminal cases" and "civil cases" in close proximity, but neither ever spoke about "criminal controversies." Indeed, that latter phrase does not appear in the records of the Virginia convention's debate on Article III. ${ }^{58}$ Correlative support for the claim that controversies were distinctively civil comes from an amendment considered in Pennsylvania and actually proposed by the Virginia convention that dealt with the vexed issue of jury trials in noncriminal proceedings. The amendment would have secured the jury trial in "controversies respecting property, and in suits between man and man."

Next, if controversies include criminal actions, then under Article III a State could prosecute a citizen of another State in the federal courts, perhaps in the Supreme Court of the United States. Some determined opponents of the Constitution, including Patrick Henry himself, denounced the state-party jurisdiction without mentioning this awful possibility, which suggests it had not occurred to them. ${ }^{60}$ At least two anti-federalists did raise this

years subsisted between the provinces of New Hampshire and New York," id at 140-41.

\$5 Bouvier defined a "dispute" as a "conversation between two persons who are of a different opinion in relation to a particular matter; a contest as to some right." Bouvier, Law Dictionary at 470 (3d ed) (cited in note 47 ).

${ }^{5}$ On this point I agree with Pushaw. See Robert J. Pushaw, Jr., Article III's Case/Controversy Distinction and the Dual Functions of Federal Courts, 69 Notre Dame L Rev 447, 464 (1994).

${ }^{87}$ Kaminski and Saladino, eds, 10 Documentary History at 1425 (cited in note 53) (A reader of the Constitution would find that jury trial is not excluded "in civil cases, and that it was expressly provided for in criminal cases.") (Pendleton); id at 1453 (Jury trial "is not excluded in civil cases, nor is a jury from the vicinage in criminal cases excluded.") (Randolph).

${ }^{4}$ Moreover, a LEXIS search conducted on October 14, 1996, in the US Supreme Court file for references to "criminal controversy" or "criminal controversies" produced no cases.

${ }^{89}$ For the Pennsylvania version, see Jensen, ed, 2 Documentary History at 597 (cited in note 50); the Virginia version is at Kaminski and Saladino, eds, 10 Documentary History at 1552 (cited in note 53).

${ }^{6}$ See Speech of Henry to Virginia ratifying convention, in Kaminski and Saladino, eds, 10 Documentary History at 1423 (cited in note 53); Brutus 13, in John P. Kaminski and Gaspare J. Saladino, eds, 16 The Documentary History of the Ratification of the Constitution 172-75 (State Hist Socy Wis 1986). This group also included the formidable, not to mention voluble, Luther Martin. Luther Martin, The Genuine Information Delivered to the Legislature of the State of Maryland, in Herbert J. Storing, ed, 2 The Complete AntiFederalist 27, 69-70 (Chicago 1981). 
specter and what they said is revealing. Centinel, addressing Pennsylvania, wrote:

This jurisdiction also goes to controversies between any state and its citizens; which, though probably not intended, may hereafter be set up as a ground to divest the states, severally, of the trial of criminals; inasmuch as every charge of felony or misdemeanour, is a controversy between the state and a citizen of the same: that is to say, the state is plaintiff and the party accused is defendant in the prosecution. ${ }^{61}$

Centinel had to distort Article III in two ways to reach his conclusion: the federal judicial power does not extend to cases between a State and its own citizens, and, as he recognized, the controversy-denominated jurisdiction was not intended to reach criminal proceedings. Moreover, in order to make criminal prosecutions sound like controversies, Centinel had to describe prosecutions so as to make them seem as much as possible like civil suits, even calling the government the "plaintiff," as if it were one more private disputant.

Agrippa, writing in Massachusetts, asserted that federal jurisdiction over state-citizen controversies would include criminal prosecutions:

This [ ] right to try causes between a state and citizens of another state, involves in it all criminal causes; and a man who has accidentally transgressed the laws of another state, must be transported, with all his witnesses, to a third state, to be tried. He must be ruined to prove his innocence. ${ }^{62}$

The Constitution, however, does not give the federal courts the right to try causes between a state and citizens of another state; it gives them the right to try controversies. It is possible Agrippa thought the two equivalent and just happened to paraphrase the Constitution rather than quoting it. It is also possible that he had a nagging awareness that "criminal controversies" would have seemed unnatural.

\footnotetext{
${ }^{61}$ Centinel 2, in Storing, ed, 2 Complete Anti-Federalist 143, 148 (cited in note 60).

${ }^{62}$ Agrippa 12, in Storing, ed, 4 Complete Anti-Federalist 93, 97 (cited in note 60). Agrippa may have made a similar assertion in his letter of January 1,1788 , where he said that "By article 3 , section 2, Congress are empowered to appoint courts with authority to try civil causes of every kind, and even offences against particular states." Agrippa 10, in Storing, ed, 4 Complete Anti-Federalist 87, 88 (cited in note 60). It is not clear whether he attributed the latter conclusion to the case-denominated or controversy-denominated heads.
} 
Centinel and Agrippa opposed ratification and were clearly reaching for anything they could find; what is interesting is that they did not just bluntly assert that controversies include prosecutions, but rather finessed the constitutional text to get to their substantive conclusions. Opponents of the thesis that controversies were limited to civil proceedings can draw some support from statements by two major figures, although the support they offer is not great. At the Pennsylvania ratifying convention, James Wilson said, "the judicial power shall extend to all cases in law and equity arising under this Constitution and the laws of the United States. Controversies may certainly arise under this Constitution and the laws of the United States, and is it not proper that there should be judges to decide them?"'63 Wilson's words suggest he thought cases and controversies interchangeable. His statement, though, is consistent with the proposition that controversies are a kind of case, and it may well have been that he had civil lawsuits in mind, especially in a day when "controversies" was widely interchangeable with "disputes."

Another Wilsonism that cuts against the civil controversies thesis appears in his Lectures on Law, where he said that the old English aula regis "was always in readiness to determine every controversy, criminal and civil." ${ }^{\prime 4}$ Later in the lectures, though, discussing jurisdiction under the American Constitution, Wilson used "controversies" in a sense that almost certainly referred only to civil proceedings. As part of his attack on sovereign immunity, he said, "In controversies, to which the state or nation is a party, the state or nation itself ought to be amenable before the judicial powers." ${ }^{255}$ In criminal proceedings the state must appear before the judiciary, but never as the defendant; the question Wilson was addressing was whether a government may or should appear as a defendant in a civil proceeding. Moreover, the difference between these contexts - one about the aula regis, the other about the Constitution-is suggestive. On the current evidence there is no reason to believe that in British English "controversy" had a meaning limited to civil proceedings; as far as we know that was strictly an Americanism. ${ }^{66}$ Hence there are two possible explanations for Wilson's reference to criminal controversies. First, he may have been using English terminology to refer to English practice. Second, he may have been using English termi-

\footnotetext{
¿ Speech of Wilson, in Jensen, ed, 2 Documentary History at 517 (cited in note 50).

a James Wilson, Lectures on Law, in Robert Green McCloskey, ed, 2 The Works of James Wilson 451 (Harvard 1967).

es Id at 497.

${ }^{\infty}$ See notes $45-47$ and accompanying text.
} 
nology because, having been born and received his early education in Scotland, he had not fully adopted American legal idioms. ${ }^{67}$

The other source of equivocal support for equating cases and controversies is the natural-born genius of American constitutional law, John Marshall. Praising Article III in the Virginia ratifying convention, Marshall said, "Here are tribunals appointed for the decision of controversies which were before, either not at all, or improperly provided for." ${ }^{368}$ Marshall may have been using "controversies" as a general term that included civil and criminal proceedings, or he may have been referring to the controversy-denominated heads of jurisdiction. Perhaps most likely, he may not have been paying perfect attention to detail. This is, after all, the man who would make a tasty meal of some of his own off-hand remarks in Marbury years later in Cohens $v$ Virginia. ${ }^{69}$

On balance, additional research supports Iredell and Tucker. The second point I wish to emphasize is the connection between the use of "controversies" and the general assumption that sovereigns do not enforce one another's criminal laws. Iredell accounted for the use of a word that was limited to civil proceedings by invoking that standard notion. ${ }^{70}$ That principle seems to have been in circulation when the Constitution was adopted. ${ }^{71}$

\footnotetext{
${ }^{57}$ Moreover, despite Wilson's wide learning (some might call it pedantry), his use of these terms was sometimes imprecise. Describing the Judiciary Act of 1789 in his Lectures on Law, he said, "The district courts have, in the first instance, exclusive cognizance of all causes of admiralty and maritime jurisdiction." Wilson, Lectures, in McCloskey, ed, 2 Works of James Wilson at 457 (cited in note 64). What they actually had was "exclusive original cognizance of all civil causes of admiralty and maritime jurisdiction." Judiciary Act of $1789 \S 9,1$ Stat at 77. Their jurisdiction over criminal admiralty cases, such as crimes committed on the high seas, was limited, and what they had was shared with the circuit courts. Id at $\$ \S 9,11$.

* Kaminski and Saladino, eds, 10 Documentary History at 1430 (cited in note 53).

5919 US (6 Wheat) 264, 399-402 (1821) ("general expressions" in Marbury were dicta). Whatever Marshall thought about the difference between cases and controversies, he thought the following about Congress's power to make exceptions to the appellate jurisdiction of the Supreme Court:

The Honorable Gentleman [apparently Patrick Henry] says, that no law of Congress can make any exception to the Federal appellate jurisdiction of fact as well as law. He has frequently spoken of technical terms, and the meaning of them. What is the meaning of the term exception? Does it not mean an alteration and diminution? Congress is empowered to make exceptions to the appellate jurisdiction, as to law and fact, of the Supreme Court.-These exceptions certainly go as far as the Legislature may think proper, for the interest and liberty of the people.

Speech of John Marshall to Virginia ratifying convention, in Kaminski and Saladino, eds, 10 Documentary History at 1437 (cited in note 53).

${ }^{70}$ See Chisholm, 2 US at 431-32.

${ }^{7}$ See, for example, Warder v Arell, 2 Va (2 Wash) 282, 295 (1796) (Roane); The Ante-
} 
That is not to say that Americans at the time of the framing thought there was some sort of logical contradiction or gross political error in allowing federal courts to hear state criminal prosecutions, or vice versa. At the Federal Convention itself, the New Jersey plan, presented to the Convention by William Paterson, provided for the trial of certain offenses against the national laws in state court, with appeal to federal court. ${ }^{72}$ And as we will see presently, there is reason to believe that the Convention, although it did not adopt the New Jersey plan, did authorize the courts of one level of government to entertain criminal prosecutions under the laws of the other. ${ }^{73}$ As applied to the new government of America, then, the penal law maxim was a baseline or default option, not an absolute rule. Nevertheless, the fact that several heads of jurisdiction are confined to controversies likely reflects the influence of the maxim.

Orthodoxy's distinction between cases and controversies is not, of course, unchallenged. Unlike Amar, who sometimes equates these terms, Robert Pushaw acknowledges that at the time of the framing there was a distinction between cases and controversies. He argues, however, that it was not, or was not primarily, the distinction between a general term for lawsuits and one that applied only to civil proceedings. Rather, according to Pushaw, the difference was that in a case the court's main function was the exposition of the law, whereas in a controversy its main function was resolution of the particular dispute before it. ${ }^{74}$ Although he casts doubt on the theory that controversies are limited to civil cases, he believes that it "complements, rather than contradicts" his thesis. ${ }^{75}$

The most severe difficulty with this theory is that it has no Iredell and no Tucker. Pushaw's evidence for framing-era usage is based on statements seemingly driven by or consistent with his

lope, 23 US (10 Wheat) 66, 123 (1825); William Rawle, A View of the Constitution of the United States of America 200 (Nicklin 2d ed 1829); Joseph Story, Commentaries On the Conflict of Laws $\$ \$$ 619-21 at 1013-15 (Little, Brown 3d ed 1846).

${ }_{72}$ Farrand, ed, 1 Records of the Federal Convention at 243 (cited in note 34).

${ }^{23}$ The convention's plan might be characterized as a departure from the maxim, but I think it more accurate and more telling to say that the Convention revised the notion of sovereignty to suit itself. See text accompanying notes 107-15.

"Pushaw, 69 Notre Dame L Rev at $449-50$ (cited in note 56). Pushaw's primary concern is to criticize the jurisdictional doctrines that keep the federal courts from providing advisory opinions and deciding questions of public right at the behest of private persons. He suggests the Court has improperly applied the dispute-resolution model appropriate to controversies to what should be the broader realm of cases. See id at 519 . Why it would make sense to authorize advisory opinions in admiralty cases, but not when two States of the Union have a legal disagreement is unclear.

${ }^{75}$ Id at $460-64$. 
distinction; no one comes out and says what he thinks they meant. Pushaw thus lacks direct evidence for his claim. Second, the law-expounding theory of cases fits best with the federal question jurisdiction (with which moderns are obsessed) but poorly with foreign officer jurisdiction. ${ }^{76}$ Especially with respect to consuls, foreign officer cases mainly would be ordinary civil litigation. Their distinctive feature would be the privileges of foreign personnel, a question of the law of nations on which the exposition of some American court would be of little interest to the principal law-makers, the Powers of Europe. The foreign officer jurisdiction exists to ensure the applicable law will be applied impartially by judges who have the national interest in mind. It is a dispute-resolving, not a law-expounding, head of jurisdiction.

Third, if the system was set up with a focus on judicial exposition of the law, it was designed badly. America was not England; it had primitive facilities for the recording and transmission of judicial opinions. ${ }^{77}$ Neither the Constitution nor the Judiciary Act of 1789 provided for the delivery of written opinions, let alone their public distribution. Indeed, although it is now conventional to label the first volume of Dallas's Reports as the first of the United States Reports, it might be more accurate to give the latter number to 14 US, the initial volume prepared by Henry Wheaton, the Supreme Court's first official reporter. Before the Wheaton era, year after year and case after case went by in which Congress left an important constitutional function to unofficial reporters who indiscriminately reported opinions in both cases and controversies.

b) The uses of "all." The textual force of Amar's two-tier theory derives from its ability to explain the appearance and nonappearance of the word "all" in Section 2 of Article III. ${ }^{78}$ The foregoing discussion of the meaning of "cases" and "controversies" makes possible an alternative account, under which Congress has no obligation to ensure that some federal court hear every lawsuit that comes within a case-denominated head of jurisdic-

\footnotetext{
${ }^{76}$ A corrective to excessive fascination with the federal question jurisdiction is Wythe Holt, "To Establish Justice": Politics, the Judiciary Act of 1789, and the Invention of the Federal Courts, 1989 Duke L J 1421.

${ }^{77}$ The chaotic state of reporting and judicial structure generally at the time of the framing is discussed in fascinating detail in Wilfred J. Ritz, Rewriting the History of the Judiciary Act of 1789 27-52 (Oklahoma 1990). See also John H. Langbein, Chancellor Kent and the History of Legal Literature, 93 Colum L Rev 547, 571-78 (1993) (American case reporting system at time of framing was undeveloped and unreliable).

${ }^{73}$ William Casto has observed that the change from "all cases" to "controversies" may have been a drafting accident. Casto, 7 Const Comm at 90 (cited in note 41). That hypothesis is sufficient but not necessary to reject the two-tier reading.
} 
tion. The alternative account comes in a modest and a slightly more aggressive form. The modest version simply asserts that "all" is there to emphasize the criminal-civil distinction. The more aggressive version asserts that, in addition, "all" indicates that the case-denominated heads of jurisdiction may include criminal prosecutions under state law. For each of the two readings, I will provide an explanation of how it represents a familiar way of using the word "all," and an explanation of why it would make sense for the Constitution to have that meaning. Because the second reading-according to which "all" signals that state criminal prosecutions may take place in federal court-is the less obvious, I will also present evidence that such a reading would have seemed reasonable at the time of the framing.

$i$. The criminal-civil distinction: emphasis. Cases include criminal prosecutions while controversies do not. "All" can clarify that point. Where the name of a general category appears in conjunction with the name of a part of that category, "all" can emphasize that the broader term does indeed have a more general meaning. Consider, for example, the statement "Canines are four-legged and dogs are easily domesticated." In what sense is "canines" being used here? Maybe it is just stylistic variation, a ten-dollar word for "dogs." On the other hand, maybe the writer is appealing to the more technical sense in which "canines" refers to the genus canis, one part of which is the species canis familiaris (Fido, for example). A judicious use of "all" can dispel this confusion. "All canines are four-legged and dogs are easily domesticated" more clearly asserts that wolves and jackals too are quadrupeds but that only homo sapiens' best friend is easily domesticated. In the same way "all" in Article III emphasizes that cases include criminal proceedings although controversies do not.

This is a substantively likely reading of the text: All of the case-designated heads of jurisdictions-the first tier of the judicial power-can easily involve criminal proceedings. First, each of the federal-question heads can involve such proceedings. Criminal prosecutions under federal statutes need a home and find it in the jurisdiction over cases arising under the laws of the United States. The Constitution provides, and federal treaties may provide, defenses against certain state criminal proceedings, so those jurisdictional categories should also extend to prosecutions. Next, federal power and federal jurisdiction naturally attach when the foreign relations of the United States are implicated, as they would be by any criminal action against a foreign 
diplomatic or consular officer. ${ }^{79}$ Finally, that admiralty courts administered criminal law as well as deciding civil disputes was commonplace at the end of the eighteenth century. ${ }^{80}$

The limitation of the controversy-denominated heads of jurisdiction-which constitute the second tier of judicial power-to civil proceedings also makes 'good substantive sense. Most of those cases would be between individuals, so the term that underlines the private nature of such disputes would fit best. Similar reasoning applies to the extent that Article III was designed to eliminate jurisdictional barriers to lawsuits by private people against States; those would be civil actions. As for the inter-State jurisdiction, a sensible drafter would not want to create the impression that the Constitution contemplated the bizarre possibility of a criminal prosecution of one State by another. Finally, the problem of state-court partiality in suits by States against out-ofstate Americans or foreigners would be especially pronounced in civil proceedings, where the defendant would not necessarily enjoy the full panoply of common-law protections granted defendants in criminal cases. Although, as I will presently argue, the Constitution does contemplate the unusual step of committing the trial of crimes against a State to courts not entirely of that State, that was an unusual step, not to be taken without good reason.

ii. State-law criminal prosecutions in federal court. It is easy enough to conclude that the case-denominated heads of jurisdictions include criminal trials while the controversy-denominated heads do not. The use of "all" would be even more significant, however, and its presence even better explained, if it were performing an additional function along similar lines. There is good reason to believe that it is doing so by indicating that the federal jurisdiction over cases includes prosecutions under state law.

There are various ways in which the word "all" can clarify the scope of a statement that uses a plural noun. As Amar says, there can be doubt as to whether such a noun refers to all members of the class it names or only some of them. He thinks that

\footnotetext{
${ }^{79}$ As will appear more fully below, see text accompanying note 90 , although ambassadors and public ministers were generally privileged from criminal punishment, consuls were not. Moreover, there was nothing to keep the United States from entering into a treaty waiving the privilege for diplomats.

${ }^{\infty}$ William Blackstone, 4 Commentaries on the Laws of England *265-66 (describing criminal jurisdiction of English high court of admiralty) (Chicago 1979); Story, 2 Commentaries on the Constitution $\S 1673$ at $443-44$ (cited in note 48) (American criminal admiralty jurisdiction extensive). Article III, Section 2 , clause 3 ensured that all crimes would be tried to a jury, obviating the fear that federal admiralty courts might follow the civil law even in prosecutions.
} 
Article III is a context in which the doubt is between the mandatory inclusion of all cases and the mandatory inclusion of some but not all cases. ${ }^{81}$ An example is the statement "Students will come to this event," which might mean either "Some students will come to this event" or "All students will come to this event." As I will discuss below, it is very difficult to believe Article III is that kind of context.

There is, however, a related usage of "all" that makes much more sense of the text. Sometimes a general noun is used in a context in which the reader has reason to believe that the noun nevertheless might refer only to a particular subclass, or that it might exclude a particular subclass. This ambiguity seems especially likely to arise with respect to rules and commands. Consider, for example, the rule "Vehicles must stop at red lights." No one would think that meant "There must be some vehicles that stop at red lights but it does not matter which ones they are." One nevertheless might think that only some vehicles must stop at red lights because emergency vehicles are implicitly exempted from the rule. "All vehicles must stop at red lights" would imply that even emergency vehicles are included. "All vehicles must stop at red lights and non-emergency traffic must remain stopped until the light has turned green" even more clearly implies that emergency vehicles must stop at red lights, in part because it indicates that they then may proceed before the light turns green.

Just as there may be a presumption that emergency vehicles are exempt from ordinary traffic laws, American law at the time of the framing and since has included the expectation that the courts of one sovereign will not enforce the criminal laws of another. Knowledge of that principle, however, only puts us on guard to look for the issue in reading Article III. The compound republic of America recasts traditional notions of sovereignty and does not necessarily follow any earlier pattern.

Reading Article III with this issue in mind, one notices there is a tier of jurisdiction in which the maxim does apply, because there is a set of rules that reaches only controversies, which are non-criminal cases. One then notices that the earlier rules use "cases," a word that might reject the maxim because it includes all lawsuits, civil and criminal. That word, but not the more limited word, is consistently preceded by "all." The word "all," this pattern suggests, indicates the rule concerning cases is as broad as it might be. On this account, "all" tells us that in the case-

\footnotetext{
"Amar, $138 \mathrm{U} \mathrm{Pa}$ L Rev at 1652-53 (cited in note 14).
} 
denominated heads of jurisdiction, federal courts will entertain state criminal prosecutions.

Using "all" to indicate that the maxim does not apply, that the state and federal governments are not foreign to one another for these purposes, is a familiar employment of the word. It is also easy to see how it would be desirable for the Constitution to include state criminal proceedings in the case-denominated heads of jurisdiction. Moreover, there is reason to believe that such a reading would have made sense in the early days of the Constitution. I will consider each of the case-denominated heads of jurisdiction in turn.

a) Federal questions. The Constitution contemplates state prosecutions in which defenses arise from the Constitution, statutes, and treaties. Federal jurisdiction is a way to make sure those federal defenses stick. One form of federal jurisdiction is appellate: Congress may arrange for a federal court to review the work of a state court in order to ensure compliance with federal law. Sometimes, however, there may be reasons to keep the proceeding out of state court altogether. A state judiciary hostile to some federal program might so manipulate the trial process as to make appellate review inadequate, or the cost of trial on a charge that should have been dismissed might prejudice federal interests. In such situations, full vindication of federal law may require a federal forum from the outset.

Although federal defenses must be fairly tried, they will not always succeed. Congress, for example, might provide a defense of good faith but the proof might show bad faith and state-law guilt besides. When that happens the federal court may be called upon to enforce a state criminal law. On appeal, the federal court may affirm the state conviction, thus participating in the infliction of punishment, or even grant execution itself. A federal trial court in which a federal defense fails will find itself enforcing state criminal law in a more straightforward way. These familiar exercises of the federal question jurisdiction depart from the maxim about penal statutes.

Moreover, the claim that there could be federal jurisdiction over state criminal proceedings was a respectable, albeit controversial, proposition of law around the time of the framing. Section 25 of the Judiciary Act of 1789 , for example, provided for federal appellate jurisdiction over state criminal prosecutions in some circumstances. ${ }^{82}$ In his 1790 report on the judiciary, Attorney General Randolph proposed to eliminate federal appellate ju-

\footnotetext{
1 Stat at $85-86$
} 
risdiction over state courts by arranging that cases within the federal jurisdiction would get into federal court as soon as possible. To that end, his draft bill provided for pretrial removal of cases in state court that presented federal questions. ${ }^{83}$ In 1815 , facing opposition in New England to the War of 1812 and its accompanying taxes and commercial regulations, Congress provided for removal of state-law prosecutions against customs officers for acts done pursuant to federal duty. ${ }^{84}$ When a similar provision was included in the Force Act of $1833,{ }^{85}$ Senator William Wilkins of Pennsylvania, Chairman of the Judiciary Committee, maintained that "Congress had the power to give this right in criminal as well as in civil cases, because the second section of the third article of the constitution speaks of 'all cases in law and equity;' and these comprehensive terms cover all." ${ }^{86}$

When the issue of removal jurisdiction finally came before the Supreme Court in 1880, the Court upheld removal. ${ }^{87}$ Justice Strong explained that removal of civil cases under the federal questions heads had "long since passed beyond doubt," and that "[t]he judicial power is declared to extend to all cases of the character described, making no distinction between civil and criminal." ${ }^{\prime 8}$ The Court clearly was not troubled by the prospect of a state criminal prosecution proceeding to judgment in a federal court. $^{89}$

${ }^{3}$ Edmund Randolph, Report of the Attorney-General to the House of Representatives, in Maeva Marcus, ed, 4 The Documentary History of the Supreme Court of the United States, 1789-1800 128, 155 (Columbia 1992).

Nonintercourse Act of $1815 \S 8,3$ Stat 195, 198, reenacted by Act of Mar 3, 1815 $\S 6,3$ Stat 231, 233-34.

$\approx 4$ Stat at 633.

${ }_{6}^{66}$ Joseph Gales and William Winston Seaton, 9 Register of Debates in Congress 261 (Gales and Seaton 1833).

${ }^{\prime 2}$ Tennessee $v$ Davis, 100 US 257, 271 (1880). There are two questions in Davis, one of which is quite tricky. The first is whether Congress may provide for removal of a state criminal prosecution that involves a federal question. The second, implicating all the difficulties of Osborn and the so-called "protective jurisdiction," is how much of a federal ingredient it takes to raise a federal question, and whether the presence of an officer who was acting within the scope of federal duty is enough. Justice Clifford, who dissented in Davis, seems to have agreed that removal is permissible when the case "involves some question arising under the Constitution, the laws of Congress, or treaties made, or which shall be made, under their authority." Id at 293 (Clifford dissenting) (citation omitted).

Davis, 100 US at 265 (majority opinion).

${ }^{8 y}$ To the objection that requiring the State to prosecute criminals in another government's courts violates state sovereignty, Justice Strong answered:

The argument so much pressed upon us, that it is an invasion of the sovereignty of a State to withdraw from its courts into the courts of the general government the trial of prosecutions for alleged offenses against the criminal laws of a State, even though the defence presents a case arising out of an act of Congress, ignores entirely the dual character of our government. It assumes that the States are completely and in all respects sovereign. But when the national government was formed, some of the 
b) Foreign officers. State criminal prosecutions in federal court under the federal question jurisdiction fit naturally into the constitutional scheme. So do state criminal prosecutions against consuls under the foreign officer jurisdiction, which extends to "all Cases affecting Ambassadors, other Public Ministers and Consuls." On one hand, the rationale for federal jurisdiction over lawsuits involving foreign officers was clear. Such proceedings implicated the foreign relations of the United States and hence should proceed in a competent, independent tribunal that was attached to the interests of the nation as a whole. On the other hand, consuls, unlike ambassadors and other public ministers, were subject to all the laws and municipal regulations of the place where they resided..$^{90}$ In America in 1789 that meant the laws and regulations of leading seaports, like Boston, New York, Philadelphia, and Charleston; consuls, unlike public ministers, were unlikely to be confined to the national seat of government.

Added together, federal-court jurisdiction over consuls and state substantive authority over them yield application of state law, including state criminal law, in federal court. ${ }^{91}$ This reasoning implies that Congress could provide that offenses by con-

attributes of State sovereignty were partially, and others wholly, surrendered and vested in the United States. ... [W] hen the Constitution was adopted, a portion of that judicial power became vested in the new government created, and so far as thus vested it was withdrawn from the sovereignty of the State.

Id at 266-67. A mandatory theorist's heart might leap up at the implication that, because some jurisdiction had been taken away from the States, only federal courts could finally determine questions within the federal jurisdiction. Justice Strong, however, went on to note, without any hint of criticism, that the Judiciary Act of 1789 "did not attempt to confer upon the Federal courts all the judicial power vested in the government." Id at 267.

${ }^{90}$ United States v Ravara, 2 US (2 Dall) 297, 297-98 (Cir Ct D Pa 1793) (consul subject to criminal prosecution); $1 \mathrm{Op}$ Atty Gen 41, 42 (1794) (consul not an ambassador or public minister because not a representative, and not entitled to privileges of public ministers); 1 Op Atty Gen 77, 78 (1797) (consul not a minister and not privileged from legal process); Wyndham Beawes, 1 Lex Mercatoric 419 (Baldwin 6th ed 1813) (Joseph Chitty, ed) (consul not minister, not under protection of the law of nations; doubtful whether consul privileged from arrest); James Kent, Commentary on International Law 131-32 (Deighton, Bell 2d ed 1877) (consuls subject to civil and criminal laws of receiving state); Henry Wheaton, Elements of International Law 423 (Little, Brown 2d ed 1863) (William Beach Lawrence, annotator) (consuls not public ministers; subject to local civil and criminal law). Among the traditional authorities, only Vattel seems to have endorsed consular immunity from ordinary criminal laws, and he did not do so unequivocally. Emmerich de Vattel, The Law of Nations 148 (Johnson 1863) (Joseph Chitty, trans) (consul's functions are "not so great as to procure ... the independence enjoyed by public ministers," but do "seem [ ] to require that the consul should be independent of the ordinary criminal justice of the place where he resides," unless he commits "some enormous crime").

${ }^{91}$ There is no reason to believe Congress was expected to adopt a criminal code for consuls, especially because consuls were expected to be subject to all the various local regulations that might be enforced criminally. See DuPonceau, Dissertation at 33 (cited in note 54). 
suls against state laws would be prosecuted in federal tribunals. ${ }^{92}$ In the Judiciary Act of 1789 , Congress appears to have done so. Section 9, which dealt with district courts, gave them "jurisdiction exclusively of the courts of the several States, of all suits against consuls or vice-consuls, except for offences above [the general criminal jurisdictional limits given district courts earlier in the section]." Although one might wonder whether suits include criminal prosecutions, the exclusion of criminal offenses with a punishment above the stated level strongly indicates that a prosecution with potential punishment below that level would be within the jurisdiction. Section 13 of the 1789 Act gave the Supreme Court "original, but not exclusive jurisdiction of all suits ... in which a consul, or vice consul, shall be a party." ${ }^{.94}$ If Section 9 does indeed tell us that suits include criminal prosecutions, then the Supreme Court had original jurisdiction over any criminal prosecution of a consul. Unless consuls were exempted from the ordinary criminal law of the States, or federal-court jurisdiction ousted the States' substantive authority, under the 1789 Act state-law prosecutions of consuls could, and prosecutions of consuls for petty crimes had to, proceed in federal court.

Although this idea may seem strange to us, and no doubt seemed strange to some people when the Constitution was new, it did not seem strange to everyone around the time of the framing. Peter DuPonceau, one of the leaders of the American bar during the early years under Article III and the 1789 Act, and a careful student of the intricacies of federal jurisdiction, thought that this was precisely the correct answer: prosecutions of consuls for violations of state criminal law should proceed in federal court. DuPonceau reasoned that the judicial power under Article III extended to cases not covered by any law that Congress was authorized to adopt, and in particular that it extended to all cases involving consuls even though Congress lacked authority to

${ }^{42}$ In saying this I am not reading United States $v$ Hudson \& Goodwin, 11 US (7 Cranch) 32 (1812), let alone Erie Railroad Co $v$ Tompkins, 304 US 64 (1938), into the Constitution. Even if the Constitution contemplates some criminal prosecutions for violations of unwritten federal law (or offenses against the United States that have not been defined by Congress), or of unwritten general law, it also contemplates some criminal law that is identifiably the law of a State, such as an ex post facto criminal statute. My point is that even a dedicated believer in inherent federal judicial power to punish offenses against federal sovereignty would have agreed that there was such a thing as the criminal law of a State and that a consul could violate it.

${ }^{\$ 3} 1$ Stat at 77. The criminal jurisdiction of the district courts extended to offenses for which the punishment was not more than whipping not exceeding thirty stripes, a fine not exceeding one hundred dollars, or imprisonment not exceeding six months. Id.

${ }^{4}$ Id at $80-81$. 
provide a comprehensive civil and criminal code for consuls. ${ }^{95} \mathrm{He}$ concluded that state law was applicable, albeit in federal court, and that in such a case "the federal tribunal is to stand precisely in the place of the State Judges, and to administer justice in the particular case, as these should have done, if the jurisdiction had not been taken from them, and vested elsewhere." ${ }^{.96}$

DuPonceau also maintained that existing decisions favored his view. One, United States $v$ Ravara, was a criminal prosecution in federal Circuit Court against Joseph Ravara, the Genovese consul. Ravara was accused of attempting to extort money from, among others, the British Ambassador and President Washington. ${ }^{97}$ The case is best known as a federal common law prosecution - that is, a criminal proceeding brought in federal court in the name of the United States without an explicit federal criminal statute. ${ }^{98}$ DuPonceau maintained the underlying substantive criminal law actually had been that of Pennsylvania. ${ }^{99}$ Whether DuPonceau was right is a subject of current scholarly dispute. ${ }^{100} \mathrm{He}$ was on stronger ground in claiming support from Chief Justice Tilghman's opinion in Commonwealth $v$ Kosloff, a rape prosecution against a Russian consul that was dismissed from Pennsylvania court on the ground that federal jurisdiction over consuls was exclusive. ${ }^{101}$ After concluding that his

${ }^{95}$ DuPonceau, Dissertation at 33-34 (cited in note 54). "It must not be believed that our Constitution has given to the national legislature powers co-extensive with those that it has conferred upon the judiciary." Id at 32. DuPonceau then went on to deny that Congress had power to legislate as to any matter that could come up in, for example, a diversity case. As for ministers and consuls in particular, he found it clear "that Congress have not the power given to them to legislate upon all matters that may affect these personages." Congress could not adopt a complete code for ministers and consuls, nor could it free consuls from the ordinary laws of the States. Id at 32-33.

${ }_{96}$ Id at 35 (footnote omitted).

${ }^{97} 2$ US (2 Dall) 297 (Cir Ct D Pa 1793).

ss The fact that the prosecution was pursued by the United States district attorney in the name of the United States did not necessarily mean the criminal law involved was federal. In the simplest criminal case, all three important government elements-the law, the prosecutor, and the court-are associated with the same government. Once that symmetry is broken, it is not immediately clear which combination is correct. Today we would say that the law and the prosecutor should go together, whatever court they are in, but we have had a long time to sort things out.

${ }^{9}$ DuPonceau, Dissertation at 36 (cited in note 54).

${ }^{100}$ Compare Robert C. Palmer, The Federal Common Law of Crime, $4 \mathrm{~L}$ \& Hist Rev 267, 301-05 (1986) (Pennsylvania common law applied), with John D. Gordon III, United States v. Joseph Ravara: "Presumptuous Evidence," "Too Many Lawyers," and a Federal Common Law Crime, in Marcus, ed, Origins 106, $137-40$ (cited in note 49) (federal common law applied). Gordon points out that DuPonceau had been one of Ravara's counsel and suggests that DuPonceau remembered the case inaccurately. Id at 107.

${ }^{101} 5$ Sergeant \& Rawle 545 (Oyer \& Terminer, Phil, $\mathrm{Pa} 1816$ ). During his discussion of the jurisdictional issue, Tilghman observed: "Accordingly we find it provided, by the 2d sect. of the $3 \mathrm{~d}$ article of the Constitution, that the judicial power shall extend 'to all cases 
court lacked jurisdiction, Tilghman gave a broad hint that Kosloff should be prosecuted in federal court, probably under Pennsylvania law. ${ }^{102}$ Such a prosecution was one reasonable solution to the puzzle posed by federal jurisdiction based on the identity of consuls rather than the applicable law.

c) Admiralty and maritime cases. If this thesis is sound, the Constitution also permits Congress to include state criminal prosecutions under the admiralty jurisdiction. The rationale for doing so is just the extension to criminal cases of the rationale for the admiralty jurisdiction generally. Matters connected with ships and shipping implicated the foreign commercial and political relations of the United States. Freedom from local bias would keep the new Republic out of a lot of trouble. If that was true about disputes over mariners' wages, it was also true about

affecting Ambassadors, other public ministers, and Consuls.' Words more comprehensive cannot be devised. They include suits of every kind civil, and criminal." Id at 548 . Tilghman had earlier rejected the claim that consuls are immune from criminal prosecution, distinguishing them from ambassadors and public ministers. Id at 545-47. In 1806 Tilghman had written the opinion of the Supreme Court of Pennsylvania dismissing a civil suit against a consul on the grounds that the federal jurisdiction was exclusive. (DuPonceau represented the consul.) See Mannhardt $v$ Soderstrom, 1 Binney 138, 144-45 (Pa 1806).

In South Carolina the state courts exercised criminal jurisdiction over consuls, holding that federal jurisdiction was not exclusive. State $v$ De La Foret, 2 Nott \& McCord 217, 222-25 (Const Ct SC 1820) (3d ed 1860). In that case Justice Abraham Nott of the South Carolina Constitutional Court, dissenting, argued that the federal jurisdiction over consuls was exclusive because of the word "all." Id at 228-29. His form of two-tierism, however, seems not to have been Amar's, but rather the strain according to which federal exclusivity meant real exclusivity: he appears to have believed a state court could not decide, even in the first instance, a case that arose directly under federal law. Id at 229. Justice Huger, writing for the majority, had this to say about Nott's textual criticism:

I cannot perceive, that the introduction of the word 'all' has produced the smallest effect on the meaning of this section. Were it omitted altogether, or attached to every branch of the section, its meaning would be the same. 'My estate' means all my estate, and 'all my estate' can mean nothing more than my estate.

Id at 223 (emphasis omitted).

102 But upon mature reflection, I am unable to deny, that the Courts of the United States can take cognizance, when I find it written in the Constitution, that the Supreme Court shall have jurisdiction in all cases affecting $a$ Consul. Is he not affected in criminal cases, much more than in civil? How then can I say, that the Supreme Court has no jurisdiction? But how, or by what law is he to be punished, in case of conviction? Shall he be punished by the law of Pennsylvania, where the offence was committed, inasmuch as there is no other express law which reaches his case?

Kosloff, 5 Sergeant \& Rawle at 551 . That language, combined with his reaching out to decide the unnecessary question of consular privilege, suggests the Chief Justice hoped Kosloff would not go free.

William Rawle, another member of the eminent Philadelphia bar in the early period, evidently thought Kosloff should have been prosecuted in federal court under general principles of the social compact-unwritten law associated with the federal government. See Rawle, View of the Constitution at 265-66 (cited in note 71). 
crimes committed on board ship, in which foreigners might be perpetrators, victims, witnesses, or otherwise interested.

Federal admiralty jurisdiction over state criminal prosecutions was also consistent with standard principles of law at the time of the framing. First, as noted above, criminal admiralty jurisdiction was well established in $1787 .{ }^{103}$ Next, it seems very likely that the substantive lawmaking power of the States and the federal admiralty jurisdiction overlapped. States retained some authority to make law having to do with maritime matters; that is shown by the Saving to Suitors Clause of the 1789 Act, which preserved some state-court common law remedies in maritime disputes. ${ }^{104}$ Moreover, the power of the States to define and punish crimes extended to harbors, bays, and rivers within a State. ${ }^{105}$ The 1789 Act extended the admiralty jurisdiction to events taking place on waters within States, including for example seizures made on "waters which are navigable from the sea by vessels of ten or more tons burthen." ${ }^{106}$ Add up these propositions and you get state criminal laws enforced in federal admiralty courts (with, of course, trial by jury).

d) General considerations. In the discussion so far of legal principles around the time of the framing I have been careful not to go beyond saying that the position I suggest was reasonable.

${ }^{103}$ See text accompanying note 80.

${ }^{104}$ Judiciary Act of 1789 § 9, 1 Stat at 77.

${ }^{105}$ In United States $v$ Bevans, 16 US (3 Wheat) 336 (1818), Chief Justice Marshall found that Boston Harbor was within the jurisdiction of the State of Massachusetts for purposes of a federal statute punishing crimes outside the jurisdiction of any State:

As the powers of the respective governments now stand, if two citizens of Massachusetts step into shallow water when the tide flows, and fight a duel, are they not within the jurisdiction, and punishable by the laws, of Massachusetts? If these questions must be answered in the affirmative, and we believe they must, then the bay in which this murder was committed, is not out of the jurisdiction of a state ....

Id at 389. Marshall separated the question of the State's power to make law for its waters from the question of the relative jurisdiction of federal and state courts. Id at 386-87. See also Thomas Sergeant, Constitutional Law 194 (2d ed 1830) (States retain general jurisdiction over waters within their territory.).

${ }^{106}$ Judiciary Act of $1789 \S 9,1$ Stat at 77. The district courts had "exclusive original cognizance of all civil causes of admiralty and maritime jurisdiction . . . within their respective districts as well as upon the high seas.” Id. The judicial districts generally were defined by States; the Connecticut District, for example, consisted of the State of Connecticut. Id $\S 2$, 1 Stat at 73. It seems the drafters of the 1789 Act thought there was admiralty jurisdiction within the territorial limits of the States, or some of them.

This conclusion is independent of one's views on the comparative merits of The Steam-Boat Thomas Jefferson, 23 US (10 Wheat) 428, 429 (1825) (Admiralty jurisdiction is limited to ebb and flow of the tide.), and The Propeller Genesee Chief, 53 US (12 How) 443,457 (1851) (American admiralty jurisdiction extends to all navigable waters.). At the time of the framing, the States included many bays and rivers that felt the tide, such as Boston Harbor. 
Issues of federalism, and especially judicial federalism, were extremely controversial in those days, probably even more so than they are today. To expect anything like unanimity would be foolish. ${ }^{107}$ That said, it is possible to object to my argument on the ground that the prosecution of state crimes in federal courts would have seemed simply beyond the pale because it was inconsistent with the idea of dual federalism, according to which the state and federal governments were to have little contact with one another. State prosecutions belong in state court and federal prosecutions belong in federal court.

My proposed reading of Article III is also inconsistent with one strand of coterminous power theory. Coterminous power theory was an understanding of the federal system shared by many, but by no means all, commentators at and soon after the framing. It held that federal legislative, executive, and judicial power necessarily have the same scope. The main application of this principle in debates over sovereignty was as a ground for impeaching the Supreme Court's impartiality between the States and the Union. Critics of the Court, invoking the maxim of coterminous power, claimed it was biased because its federal question jurisdiction expanded whenever it upheld a congressional statute against the claim that Congress had exceeded its enumerated powers. The most extreme form of coterminous power thinking also worked in the other direction, maintaining that where there was federal court jurisdiction, there was also substantive congressional power. This last conclusion is inconsistent with my reading, according to which it is possible to have federal jurisdiction but state legislative authority. ${ }^{108}$

Neither the strongest form of dual federalism nor the strongest form of the coterminous power principle, however, was invariably endorsed in the Constitution's early years. Congress, after all, provided for federal removal of state prosecutions as early as $1815 .^{109}$ Moreover, although there was much opposition to the suggestion that federal criminal prosecutions could go forward in state courts, as Michael Collins has recently pointed out a number of leading authorities-Tucker, Sergeant, and Rawle-

\footnotetext{
${ }^{102}$ It would also be foolish to think that commentators' political views did not affect their legal opinions. By relying on DuPonceau, for example, I do not mean to suggest he did not have an agenda. I do think, however, that the arguments he mustered in support of his agenda tell us something about the range of acceptable argument.

${ }^{16}$ See White, Recovering Coterminous Power Theory at 68-70, 76-85 (cited in note 49). White does not suggest there was a coterminous power monolith; rather, his point is that coterminous power theory provided a set of frequently invoked premises that are difficult for us to understand today. Id at 69-72, 78-85.

${ }^{116}$ Nonintercourse Act $\$ 8,3$ Stat at 198.
} 
were prepared to countenance the practice to some extent. ${ }^{110} \mathrm{Co}$ terminous power theory was always strongest when asserting that the federal courts had every incentive to expand the legislative sphere of Congress because their sphere would expand with it; the notion that federal-court jurisdiction necessarily brought with it substantive congressional power seems to have been the weaker side, one on which opinion was very much divided. ${ }^{111}$

Something deeper is also at work here. The product of the Federal Convention embodied a variety of innovations and compromises. One novel intermediate measure was the Supremacy Clause, which made the law of the United States the law of every State and charged the state judiciaries to treat that law as their own. ${ }^{112}$ As for the new federal court system, it had two unusual features. First, federal jurisdiction extended to cases that involved both state and federal law and to cases that involved no federal law at all. Second, because inferior federal courts were optional and the original jurisdiction of the Supreme Court was limited, there could be some cases, including federal question cases, in which federal jurisdiction was exclusively appellate. Those cases would have to begin in state court if they were to begin anywhere, which confirms the implication that state courts were to administer federal law as their law. ${ }^{113}$

It can take a while to work out the implications of such an innovative, not to mention complicated, system. If the new ar-

\footnotetext{
${ }^{10}$ Michael G. Collins, Article III Cases, State Court Duties, and the Madisonian Compromise, 1995 Wis L Rev 39, 84-96. See Rawle, View of the Constitution at 264-65 (cited in note 71); Sergeant, Constitutional Law at 269 n (i) (cited in note 105); Tucker, ed, 1 Blackstone's Commentaries at 182 (cited in note 45). Collins discusses some of the shortcomings of an earlier classic article on this subject, Charles Warren, Federal Criminal Laws and the State Courts, 38 Harv L Rev 545 (1925). Collins, 1995 Wis L Rev at 84-89.

"'Justice Iredell in Chisholm, for example, said that the federal judicial power went as far as the federal executive and legislative power and then went further, to controversies not within the special competence of the general government. Chisholm $v$ Georgia, 2 US (2 Dall) 419, 435-36 (1793) (Iredell dissenting). DuPonceau said the same thing. DuPonceau, Dissertation at 32 (cited in note 54). In his elementary constitutional law treatise, Justice Story explained the federal question jurisdiction on the grounds that "the judicial power ought to be co-extensive with the legislative and executive powers," and then went on to give different rationales for the other heads of jurisdiction. Joseph Story, The Constitutional Class Book 132 (Hilliard, Gray 1834).

${ }^{112}$ As has been pointed out many times, the Supremacy Clause was a substitute for a congressional negative on state laws. The classic, much-quoted, statement of the result is by Hamilton in Federalist 82, which explains that the laws of the States and the Union together make "ONE WHOLE." Federalist 82 (Hamilton), in Clinton Rossiter, ed, The Federalist Papers 491, 493 (Mentor 1961).

${ }^{113} \mathrm{By}$ using that phrase I do not mean to endorse any particular position on the debate surrounding cases like Howlett $v$ Rose, 496 US 356 (1990), and Testa v Katt, 330 US 386 (1947), which consider state courts' obligations to entertain causes of action created by federal law. I think this is a very subtle problem.
} 
rangement did not completely square with some observers' theoretical principles, those observers would hammer on it until it did fit. That does not mean, however, that they were not hammering. Dual federalism, under which state and federal spheres are kept apart from one another by what has been called constitutional preemption, is only a gloss on the Constitution. ${ }^{114}$ It avoids some of the complexities that come from combining state and federal law into a single system. If the Supremacy Clause combines them, however, then the complexities avoided by dual federalism are the Constitution's own. Just as we must do all we can to understand earlier thinking in terms of its own categories, so we must be aware that earlier thinkers may have been acting on their own preconceptions in interpreting this novel phenomenon. If dual federalism is an historically authentic strand in American constitutional thought, so is James Madison's insistence that the Constitution's system of divided sovereignty cannot be captured in any formula. ${ }^{115}$

\section{Mandatory and permissive tiers.}

If the foregoing is correct, there are two tiers of federal jurisdiction and the difference between the two is that the first tier extends to criminal cases, including criminal cases under state law. Amar's two-tier theory, by contrast, maintains that under Section 2 of Article III, the jurisdiction of some federal court must extend to all lawsuits described in the case-denominated heads of jurisdiction and some lawsuits described in each of the controversy-denominated heads. This reading is subject to a series of substantive and textual objections. The first, most obvious, substantive objection is so plain that it need not detain us long. It is impossible to imagine any reason for setting a floor on the controversy-denominated jurisdiction where this theory sets it. Why, for example, require that at least two lawsuits in which

\footnotetext{
"The term "constitutional preemption" comes from Alfred Hill, The Law-Making Power of the Federal Courts: Constitutional Preemption, 67 Colum L Rev 1024 (1967). Dual federalism builds on one of the basic structural features of the Constitution: that the federal government acts directly on the people, not just on the States. The extreme form of this principle has the federal government acting only on the people, not on the States at all, and has the Constitution carving up spheres of authority for the two levels of government; the two spheres are then treated more like two territorially distinct countries than like one country with two levels of government.

${ }^{115}$ Madison wrote to Daniel Webster in 1830: "The actual system of Government for the United States is so unexampled in its origin, so complex in its structure, and so peculiar in some of its features, that in describing it the political vocabulary does not furnish terms sufficiently distinctive and appropriate, without a detailed resort to the facts of the case." Letter from James Madison to William Webster (May 27, 1830), in 4 Letters and Other Writings of James Madison 84, 85 (Worthington $2 \mathrm{~d}$ ed 1884).
} 
the United States is a party be within the jurisdiction of the federal courts? Indeed, Amar does not seem to take this possibility seriously himself. ${ }^{116}$ His response so far to such difficulties has been that his theory accounts for the text while no other can. ${ }^{117}$

There are three textual problems with Amar's account, however. First, his reading fares poorly under his own canon that it is vital to account for, and if possible give significance to, every word. Article III shifts, not from "all cases" to "cases," but from "all cases" to "controversies." According to Amar, cases and controversies are the same thing; the switch to a synonym is done to emphasize the dropping of "all."118 That interpretation is certainly creative, but normally adjectives modify nouns, not the other way around. He has not explained the change in nouns.

Second, few if any readers of Article III would reach Amar's interpretation, because his reading does not reflect the way "all" is used, either today or, as far as I can tell, in 1787. One very common use of that word is for clarity or emphasis. I argued above that Article III uses it to clarify a statement; without "all" before "cases," one might wonder whether prosecutions under state law are included. To be sure, the substantive logic of the Constitution would lead to the conclusion that state criminal proceedings do come within the case-denominated heads of juris-

"Arguably, federal courts must have the power to hear at least some miniscule subset of cases in each of the last six categories; the use of the plural, 'Controversies,' suggests that 'the judicial Power shall extend to [at least two] Controversies' in each category. As any such restriction on congressional power would be both trivial and practically unenforceable, I shall for expository ease follow the principle de minimis non curat lex, and speak as if Congress could abolish all jurisdiction in these categories.

Amar, 65 BU L Rev at 240 n 119 (cited in note 14).

${ }^{117} \mathrm{Amar}, 138 \mathrm{U} \mathrm{Pa} \mathrm{L} \mathrm{Rev} \mathrm{at} 1651$ (cited in note 14).

${ }^{118}$ Amar's initial response to the possibility that the switch from cases to controversies marks the switch from a category that includes civil and criminal cases to one that includes only civil cases was to deny the case-controversy distinction and say instead that "the different wording simply represents yet another way-in addition to the selective usage of 'all' and the distinction between party-defined and subject matter-defined jurisdiction-in which the first three jurisdictional categories were set off as structurally different from the last six." Amar, 65 BU L Rev at $244 \mathrm{n} 128$ (cited in note 14). (The casedenominated heads of jurisdiction are not all based on subject matter, unless a great deal of stress is placed on "affecting" in the foreign officer jurisdiction. That is why I keep using that cumbersome name rather than referring to them as the subject-matter heads of jurisdiction. Moreover, controversies between citizens of the same State claiming lands under grants of different States are defined as much by their subject matter as by their participants.) Amar's latest response is, “So what if 'cases' and 'controversies' mean different things? How does that account for the fact that the judicial power shall extend to ' $a l l$ ' [criminal and civil] cases in the first tier, but not necessarily all [civil] controversies in the second?" Amar, $138 \mathrm{U} \mathrm{Pa} \mathrm{L} \mathrm{Rev} \mathrm{at} 1657$ (cited in note 14) (brackets in original). I am trying to answer that question here. 
diction. Adding "all" makes it easier to reach that conclusion and more certain that one will do so.

This is how the Constitution uses "all" in other places. Everywhere else in the document other than the paragraphs at issue here, "all" either clarifies or emphasizes what was clear already. ${ }^{119}$ The clarifying or emphasizing usage also appears in the

${ }^{n 19}$ The following are the passages, in addition to the first two paragraphs of Article III, Section 2, in which "all" appears in the Constitution of 1787. It seems to me that in every one "all" clarifies without changing the sense of the statement, sometimes because it is simply a synonym for "the."

1. "All legislative powers herein granted shall be vested in a Congress of the United States." Art I, $\$ 1$.

2. The number of persons in a State for purposes of apportionment shall include the whole number of free persons plus "three fifths of all other Persons." Art I, § 2, cl 3.

3. "The Senate shall have the sole Power to try all Impeachments." Art I, § 3, cl 6.

4. Senators and Representatives "shall in all Cases, except Treason, Felony and Breach of the Peace" be privileged from arrest during their sessions. Art I, $\S 6, \mathrm{cl} 1$.

5. "All Bills for raising Revenue shall originate in the House of Representatives." Art I, § 7, cl 1 .

6. "[חn all such Cases [of presidential veto] the Votes of both Houses shall be determined by yeas and Nays." Art I, § 7, cl 2.

7. Congress shail have power to levy taxes, duties, imposts, and excises, "but all Duties, Imposts and Excises shall be uniform throughout the United States." Art I, § 8, cl 1.

8. Congress shall have power to "exercise exclusive Legislation in all Cases whatsoever" over the federal capitol territory. Art I, § 8, cl 17.

9. Congress shall have power to exercise exclusive jurisdiction "over all Places purchased" from the States for "Forts, Magazines, Arsenals, dock-Yards, and other needful Buildings." Art I, § 8, cl 17.

10 \& 11. Congress shall have power to "make all Laws which shall be necessary and proper for carrying into Execution the foregoing Powers, and all other Powers vested by this Constitution." Art I, § 8, cl 18.

12. A "regular Statement and Account of the Receipts and Expenditures of all public Money shall be published from time to time." Art I, § 9, cl 7 .

13 \& 14. When States, with Congress's consent, lay such duties on imports or exports as may be absolutely necessary for executing their inspection laws, "the net Produce of all Duties ... shall be for the Use of the Treasury of the United States; and all such Laws shall be subject to the Revision and Controul of the Congress." Art I, $\$ 10, \mathrm{cl} 2$.

15-17. The electors "shall make a List of all the Persons voted for," the President of the Senate shall "open all the Certificates" of the electoral votes, and when the House of Representatives chooses the President "a Majority of all the States shall be necessary to a Choice.” Art II, § 1, cl 3.

18. The President shall nominate and appoint "Ambassadors, other public Ministers and Consuls, Judges of the supreme Court, and all other Officers of the United States." Art II, \$ 2, cl 2.

19. "The President shall have Power to fill up all Vacancies that may happen during the Recess of the Senate." Art II, \$2, cl 3. cl 1.

20. The President "shall Commission all the Officers of the United States." Art II, § 3 ,

21. "The President, Vice President, and all civil Officers of the United States" may be removed by impeachment and conviction. Art II, $\S 4$.

22. "The Trial of all Crimes, except in Cases of Impeachment, shall be by Jury." Art III, $\S 2$, cl 3.

23. "The Citizens of each State shall be entitled to all Privileges and Immunities of Citizens of the several States." Art IV, § 2, cl 1. 
Articles of Confederation. For example, the Articles gave "the United States, in Congress assembled ... the sole and exclusive right and power ... . of establishing rules for deciding, in all cases, what captures on land or water shall be legal," and of "establishing courts for receiving and determining finally appeals in all cases of captures." ${ }^{120}$ When a power is sole and exclusive it would be very hard to conclude that it extends only to some of the instances enumerated; "all" here is clarifying, and clarifying only slightly. ${ }^{121}$

For Amar, however, "all" is not clarifying or emphasizing: it is changing the sense of the sentence from one clear meaning to another. If "all" did not appear, and Section 2 simply referred to cases and then to controversies, no one would think that all cases but only some controversies were included. Article III without "all" would not be ambiguous or unclear. It would clearly mean something other than what Amar says the actual text means. This is more than clarification. To be sure, sometimes adding "all" does change the sense of a statement. For example, "Deer walk through my back yard" means that some deer do so and is clear enough. "All deer walk through my back yard" means something else. That change of meaning is a standard way to use "all," but it is not the usage Amar attributes to Article III. If it contained no "all"s, the first paragraph of section 2 would not be read as implicitly including "some," the way the statement about deer would be; it most naturally would be read as referring to all cases and all controversies within the described categories. Amar maintains that the addition of three "all"s to a sentence that already has five implicit "all"s subtracts two of the implicit ones and changes them to "some."

24. "The Congress shall have Power to dispose of and make all needful Rules and Regulations respecting the Territory or other Property belonging to the United States." Art IV, \$ 3, cl 2.

25. Amendments, when ratified, "shall be valid to all Intents and Purposes" as part of the Constitution. Art V.

26. "All Debts contracted and Engagements entered into" before the Constitution shall continue to be valid. Art VI, cl 1 .

27. "This Constitution, and the Laws of the United States which shall be made in Pursuance thereof; and all Treaties made, or which shall be made, under the Authority of the United States, shall be the supreme Law of the Land." Art VI, cl 2.

28. "[A]ll executive and judicial Officers, both of the United States and of the several States" shall be bound by oath or affirmation to support the Constitution. Art VI, cl 3 .

${ }^{120}$ Articles of Confederation, Art IX, cl 1, reprinted in 1 Stat 4, 6 (1845).

${ }^{121}$ In similar fashion, Article IX goes on to say that the "United States in Congress assembled, shall also be the last resort on appeal, in all disputes and differences" concerning state boundaries, id at $\mathrm{cl} \mathrm{2,} 1$ Stat at 6, and gives the same authority with respect to "[a]ll controversies concerning the private right of soil claimed under different grants of two or more States," id at cl 3, 1 Stat at 7. No one would think "all" makes any difference. 
No one uses English that way. Amar has pointed to no instance in which anyone has sought to imply a "some" by adding an "all" to a sentence in which "all" already was implicit. ${ }^{122}$ As far as I know, the language has no such convention. Up to this point, Amar has fallen back on the claim that there is nothing else the words of Article III could mean.

The third textual objection is the converse of the second. Article III, I have just argued, is not a natural way of conveying what Amar says it conveys. Moreover, someone who wanted to say what Amar claims the Federal Convention wanted to say would have written something else. This is so for two reasons. First, the problem with Amar's intricate word game is that it is an intricate word game. If he is correct, the text waited almost two hundred years for its true interpreter. Constitution drafters do not engage in secret writing, because to do so will cause their enterprise to fail. If Amar's reading had been what the framers wanted to get across, they would have drafted something else. ${ }^{123}$ Second, there was an obvious way for the framers to have conveyed Amar's message, but it is not his way. The language does have a form of words that contrasts statements that apply to every member of a class with statements that apply only to some members of that class. A well known example is "All animals are equal but some animals are more equal than others." 124

\section{The Supreme Court}

When Article III finally talks about jurisdiction, it deals only with that of the Supreme Court. The Constitution sets out the

${ }^{122}$ The parade of examples in which the presence and absence of "all" do not together imply "some" includes the Appointments Clause, which provides that the President

shall nominate, and by and with the Advice and Consent of the Senate, shall appoint Ambassadors, other public Ministers and Consuls, Judges of the supreme court, and all other Officers of the United States, whose Appointments are not herein otherwise provided for, and which shall be established by Law.

US Const, Art II, $\$ 2, \mathrm{cl} 2$. No one thinks (I hope) that Congress could comply with this by providing that the Supreme Court shall consist of a Chief Justice and eight Associate Justices, two of whom shall be appointed by the President with the advice and consent of the Senate, the remainder of whom shall be named by joint ballot of the Senate and House.

${ }^{1} \approx \mathrm{By}$ contrast, if the drafters were assuming the criminal-civil distinction their plan worked so well that few people even notice it. There is today federal jurisdiction over criminal proceedings, including criminal proceedings under state law, in the casedenominated but not the controversy-denominated heads of jurisdiction. Compare Tennessee $v$ Davis, 100 US 257 (1879) (When a federal question is raised, removal of a state criminal case to federal court is constitutional.), with Wisconsin v Pelican Insurance $\mathrm{Co}$, 127 US 265 (1888) (Original jurisdiction over controversies to which a state is a party does not extend to penal actions.).

${ }^{124}$ George Orwell, Animal Farm 148 (Harcourt 2d ed 1954) (capitalization altered). 
Court's original jurisdiction and then provides that it shall have appellate jurisdiction in all the other cases previously mentioned, subject to Congress's power to make exceptions and regulations. According to the standard account, the original jurisdiction is beyond congressional control. Congress may neither add to nor subtract from it, although it is now generally accepted that Congress may create concurrent jurisdiction in inferior federal courts. Orthodoxy treats the Supreme Court's original jurisdiction as mandatory on Congress.

Rising to the challenge, Amar maintains that orthodoxy is wrong about this too. He finds two tiers everywhere. Once again, "all" is the key. Article III provides that "In all Cases affecting Ambassadors, other public Ministers and Consuls, and those in which a State shall be Party, the Supreme Court shall have original jurisdiction." According to Amar there is a missing "all" before "those," which implies the Constitution really means "some of those."

The textual argument for the standard reading is straightforward and consistent with the account of the Extending Clause developed above. The clause sets out the Court's original jurisdiction. It is mandatory in the sense that any constitutional rule is mandatory: only the power that made the rule can change it, and Congress is not that power. The clause itself, therefore, confers on the Court the power to hear and decide those cases within its original jurisdiction. Congress may need to pass some. laws that are necessary and proper for the Court to perform its function, but then Congress must pass many such laws for the government to operate. As for concurrent jurisdiction in the lower courts, the Constitution does not say that only the Supreme Court shall have jurisdiction over those cases, and it does extend to them the judicial power, which it vests in both supreme and inferior courts.

The use of the word "all" in this paragraph is consistent with the orthodox account of the text defended here. According to the reading just presented, "all" is doing little if any work. At most it reinforces what would in any event be the natural reading. Suppose the text instead read, "In Cases affecting Ambassadors ... , and those in which a State shall be party, the supreme Court shall have original jurisdiction. In the other Cases before mentioned, the supreme Court shall have appellate Jurisdiction . . . ." It is very unlikely that anyone would think the original jurisdiction extended only to some of the foreign officer cases or that the

${ }^{125}$ Amar, 56 U Chi L Rev at 480-83 (cited in note 14). 
appellate jurisdiction extended only to some of the other cases listed in the first paragraph. As noted above, this is the way "all" repeatedly functions in the Constitution.

To be sure, by this account the Supreme Court paragraph does not use "all" to reinforce the point that cases include both civil and criminal proceedings. But there is no reason for it do to so, because all that work has been done in the preceding paragraph. Once it is established that the second paragraph is allocating jurisdiction over the cases and controversies already enumerated, the distinction between cases and controversies is built in. Thus, when the text refers to all the other cases before mentioned, it includes only civil proceedings in the controversydenominated heads of jurisdiction because the first paragraph included only civil proceedings. ${ }^{126}$

Amar's mandatory-permissive division once again encounters serious textual difficulties. It makes sense to have a permissive tier only if Congress has power to remove cases from the Court's original jurisdiction. Doing so is different from adding them to the jurisdiction of the inferior courts, which it can do with the power to constitute those tribunals. But Congress has no express authority over the original jurisdiction of the Supreme Court, a point that seems especially telling given its explicit power over the Court's appellate jurisdiction. Expressio unius est exclusio alterius. Amar is left to argue that taking cases out of the Court's original docket is necessary and proper to carry into execution either the powers of the inferior courts, which seems strange, or of the Supreme Court itself, which seems very strange. ${ }^{127}$

One more problem awaits Amar's two-tier theory in this paragraph. The last sentence, which deals with the Court's appellate jurisdiction, encompasses "all the other Cases before mentioned" (subject to Congress's exceptions power, whatever it is exactly). What is this "all" doing? It is not contrasting with a parallel formulation from which "all" is missing, thereby signaling that the parallel formulation implicitly includes the word "some," because there is no parallel formulation-no list of con-

\footnotetext{
${ }^{125}$ The orthodox view of the Court's original jurisdiction, under which it extends only to those State-party cases that come to federal court because a State is a party, and thus excludes federal question and admiralty cases that have a State as a party but that lack diversity, is challenged in Pfander, $82 \mathrm{Cal} \mathrm{L} \mathrm{Rev} \mathrm{at} \mathrm{560-61} \mathrm{(cited} \mathrm{in} \mathrm{note} \mathrm{44).} \mathrm{Pfander's}$ thesis is not closely related to that of this paper, so I will pause only to note that if both Osborn $v$ Bank of the United States, 22 US (9 Wheat) 738 (1824), and Texas $v$ White, 74 US ( 7 Wall) 700 (1868), are still good precedent, under this theory the Court probably has original jurisdiction over every case in which a State is a party.

${ }^{177}$ Amar, $56 \mathrm{U}$ Chi L Rev at 481-83 (cited in note 14).
} 
troversies, not even a "those." Apparently the Constitution, in the course of a single paragraph, has returned to the practice it adopts everywhere else, of using "all" as a synonym for "the" or a clarification that general language really is totally inclusive.

\section{STRUCTURE}

Read all the text together and you can see the constitutional structure. Amar maintains that if we look at the forest and not the trees, the shape of the forest will support his reading. The independence of the federal courts, which consists in their institutional separation from the other two branches and their judges' protected tenure and salary, is part of the larger picture. Protection and independence distinguish the federal courts from the state courts, leading Amar, like others, to the conclusion that the state courts cannot have been meant to be the ultimate guarantors of federal constitutional limitations. ${ }^{128}$

Amar's structural argument works like this: The Constitution is designed to set up a complete government, with all three branches of its own. Unlike the Confederation, it is not supposed to make the national government dependent on the States for its operations; that is the difference that comes with having a national executive and a national judiciary. Moreover, the new national judiciary has structural features-national appointment, protected tenure, and national accountability--that distinguish it sharply from the state judiciaries. The state judiciaries are thus no more a replacement for the national courts than the state Governors are for the President. In light of all this, it cannot be that the Constitution leaves it to Congress to decide whether to have a fully functioning national judiciary that can play its independent role in the new constitutional scheme, any more than the Constitution leaves it to Congress whether to have a President. Any reading that gives Congress such power, and thereby threatens the completeness of the new national government and the resulting separation of powers, cannot be right. Thus, in particular, the federal courts must have authority to resolvefinally, at least-all federal jurisdiction litigation.

Traditionalists, however, do not suggest Congress has power to eliminate the federal courts as an independent branch of the national government. According to the traditional reading, at an

\footnotetext{
${ }^{123}$ See Amar, 65 BU L Rev at 229-38 (cited in note 14). I use the phrase "ultimate guarantors" in deference to Hart, who introduced it into the debate. See Hart and Wechsler at 423 (cited in note 4). Were I writing on a clean slate the phrase would be "ultimate judicial guardians." The failure to make that distinction is one of the besetting sins of this debate.
} 
absolute minimum there must be a Supreme Court with the original jurisdiction set out in Article III and with enough appellate jurisdiction to constitute a rule to which congressionally mandated exceptions are indeed exceptions. In order to make his argument plausible, then, Amar must move from the independent existence of the federal courts to a claim about their necessary jurisdiction. The structural principle on which he relies is therefore not simply the independent stature of the federal courts, but coextensiveness: the notion that the constitutional structure tells us the federal courts must have the last word on federal law.

As indicated above, coterminous power is a venerable principle. It is very doubtful, however, that it is the Constitution's principle. The most glaring departure from coextensiveness is the one remarked on by DuPonceau and many others: the federal courts have jurisdiction over quite a few cases in which none of the substantive law comes from the Constitution, a federal statute, or a federal treaty. ${ }^{129}$ If federal jurisdiction may, at Congress's pleasure, depart from coextensiveness by including cases with no federal question, it is hard to see what is wrong with departing by excluding some cases with a federal question.

Article III departs from coextensiveness. Moreover, it does not give to federal question cases special treatment that would indicate special structural status. If Clinton is right and all the heads of jurisdiction are alike, federal questions are just one among nine. Even if Amar is right and the case-denominated heads are more fundamental than the controversy-denominated heads, it is still not true that federal questions are special, other than by coming first. Federal question cases get the same treatment as foreign officer cases and admiralty cases.

Foreign officer and admiralty jurisdiction (especially the latter) are not merely federal question jurisdiction in disguise. ${ }^{130}$ At the time of the framing, admiralty, while a subject of federal interest, was only sometimes a subject of federal law. ${ }^{131}$ Rather, most admiralty cases would have been expected to turn on the general commercial law, which was derived from the practice of merchants and of the courts of commercial nations. Federal law

${ }^{22}$ The best known example of this is the diversity jurisdiction, but in 1789 the same would have been true for a great many admiralty cases, which would have been decided under the general commercial or maritime law.

${ }^{150}$ Amar is correct that a federal question that comes up in an admiralty or maritime action comes into federal court under only the admiralty jurisdiction, because the federal question jurisdiction extends only to cases in law and equity.

"'See Stewart Jay, Origins of Federal Common Law: Part Two, 133 U Pa L Rev 1231, 1266-67 (1985). 
would apply when Congress had passed a statute pursuant to one of its enumerated powers, and state law would apply when the applicable choice of law rules pointed to a local rule that varied from the general law. ${ }^{132}$ The modern approach, which eliminates the category of general law and makes admiralty part of federal law even in the absence of congressional legislationand, in fact, even in the absence of a grant of power to Congress-is just that: the modern approach. ${ }^{133}$ It is anachronistic to think that at the time of the framing admiralty cases always or even usually would have involved federal questions. ${ }^{134}$

The Constitution clearly envisions an independent federal judiciary, but it does not imply Amar's mandatory version of the principle of coextensiveness. ${ }^{135}$ Nor does it imply his principle of structural superiority, which amounts to disdain for state courts. Whatever moderns may think, and whatever many participants in the ratification debates said in an attempt to justify the existence of a federal judiciary, the Constitution is not drafted on the principle that state courts are unreliable. The document that emerged from the Federal Convention said almost nothing about state criminal law, almost nothing about state criminal procedure, and almost nothing about the structure of the state judiciaries. It thus left the citizens' lives, as well as their liberty and property, pretty much in the hands of courts and legal systems that Amar thinks the framers would not trust with the Duty of

\footnotetext{
${ }^{132}$ The old system, in which choice of law rules could point a federal court to state, federal, or general law, is lucidly explained and documented in William A. Fletcher, The General Common Law and Section 34 of the Judiciary Act of 1789: The Example of Marine Insurance, $97 \mathrm{Harv} L \mathrm{Rev} 1513$ (1984). Fletcher explains that "[b]ecause of the character of most disputes in admiralty, few admiralty cases were governed by local law. But in those cases in which local law provided the relevant rule of decision, federal admiralty courts did not hesitate to follow it." Id at 1531. The general law administered in federal admiralty courts (and in federal diversity courts and in state courts) was not federal law: state courts were not bound by the Supremacy Clauses to follow it as expounded by federal courts. Id at 1558-62.

${ }^{120}$ The proof of the pudding here is the fact that it was not until fairly late that the Supreme Court decided that the principles of commercial and navigation law announced in federal admiralty courts had the same effect under the Supremacy Clause as acts of Congress. See Southern Pacific Co v Jensen, 244 US 205, 215 (1917). That doctrine was unknown through most of the nineteenth century and certainly to the framers. In saying this I do not mean to deny that the Federal Convention sought to ensure uniform law on maritime matters. The Constitution provides for that uniformity, however, through the jurisdiction of the federal courts and Congress's power to make that jurisdiction exclusive. That technique is more complicated than simple "preemption."

${ }^{13}$ It is also possible to have a case involving a consul in which the only real federal question is one of jurisdiction, but the point is stronger with respect to admiralty.

${ }^{123}$ It is common ground in this debate that the Constitution authorizes the resolution of every federal question case by a federal court. Indeed, on the orthodox reading that is the Constitution's default option: if Congress does not exercise its exceptions power every federal question case will be within the Supreme Court's appellate jurisdiction.
} 
Tonnage Clause. ${ }^{136}$ Something has to give here, and it should be the contempt for state courts.

There is a still more serious, methodological difficulty with Amar's argument. The difficulty is that structural principles such as coextensiveness, even if identified correctly, generally lack resolving power in deciding questions of detail. This is so because structural principles are not constitutional rules, or even the aggregate of constitutional rules. Rather, they are hypothesized guidelines for design. Consider judicial independence itself. In one sense that phrase can be used simply to label the fact that judges appointed pursuant to Article III may be removed from office only by impeachment and conviction. In that sense, though, to speak of judicial independence adds nothing. It is more interesting to talk about judicial independence in the sense that refers to the ability of the courts to operate without being subject to the control of the other branches of government. That is a guideline for design.

Guidelines for design are more abstract and general than concrete constitutional provisions. The principle of judicial independence is more abstract than the protected tenure that actually appears in the Constitution. The result of this conceptual relationship is that guidelines for design-structural principles of the kind Amar relies on-do not determine the content of the rules. Rather, there usually will be various potential implementations that are all consistent with the same principle. Different sets of rules will achieve the goal of the principle in different ways and to different degrees. Judicial independence, for example, is consistent with the Constitution as we have it, with one in which a simple majority vote of the Senate is sufficient for conviction upon impeachment, and with one in which a three-fourths vote is required for conviction. To say there should be judicial independence is not to say how much independence there must be. Nor is long tenure with difficult removal the only way to ensure decisions by courts will be free from executive or legislative influence. Juries also serve that end, but do so through their brief tenure. The desideratum of independence does not dictate the manner in which it is pursued any more than it dictates the extent to which it is pursued.

Design principles underdetermine structural rules. Indeed, most of the hard work in constitutional design comes not in identifying the appropriate principles, but in deciding precisely how and to what extent to implement them. As the proceedings of the

${ }^{15}$ US Const, Art I, § 10, cl 12. 
Federal Convention demonstrate, the crucial question usually is not whether, but how and how much. One question the Convention had to address repeatedly was whether to implement a principle by putting a rule about it into the document or by giving Congress the power to make a decision.

Article I, Section 10 contains examples of both approaches. It is a principle of design, for example, that state involvement in naval warfare implicates national interests and should be subject to some form of national control. That principle, however, does not itself decide whether the Constitution should regulate the matter or empower Congress to do so. Section 10 splits the principle: States are forbidden from granting letters of marque and reprisal, but the question whether they may keep warships in time of peace is left for Congress to decide. In similar fashion, Section 10 forbids any State from entering into a treaty, alliance, or confederation, while leaving to Congress the decision whether States may enter into agreements or compacts with foreign powers.

In drawing the fine distinction between a treaty and a compact, the Federal Convention was not simply applying the principle that relations between States and foreign countries are a federal concern. It was also making nice judgments of policy on other grounds, drawing distinctions beyond the resolving power of the general principle, and perhaps recognizing that many principles have exceptions that cannot be foreseen in advance.

The principle of coextensiveness, if it is to be attributed to the Constitution, is no different from the principle that state relations with foreign sovereigns raise federal-level issues: it could be implemented either with a constitutional requirement that the federal courts finally resolve all questions of federal law, or with a power in Congress to provide that they shall do so. Which implementation is better depends on additional considerations not contained in the principle itself.

To take what may be the most common phenomenon, the principle must compete with others, such as the notion that the government should not make the citizens' lives inconvenient. The latter guideline underlies the reason most frequently given during the ratification debates for allowing Congress to curtail federal jurisdiction: the inconvenience, particularly for those of ordinary wealth, of protracted litigation. Especially if there were only a few federal courts, all of them appellate, it might not be worth the parties' money to have every case with a federal ques- 
tion decided in federal court. ${ }^{137}$ This possibility suggests why the Constitution might implement the principle of coextensiveness in a way that gives Congress substantial discretion over the actual jurisdiction of the federal courts. ${ }^{138}$

Principles interact and they compete with one another. One of the most important applications of that general truth obtains with special force in this context. Virtually every principle, every desideratum, of constitutional design is subject to limitation on the basis of the master principle of constitutional design: power is dangerous. For this reason, Presidents and Article III judges have fixed terms, except that they are subject to impeachment, conviction, and removal. Similarly, Representatives and Senators are free from arrest during their session, but only to a limited extent. And the President appoints officers, with the advice and consent of the Senate. And so on and so on. From the standpoint of any principle, checks inserted because of the possibility of abuse will seem incongruous. Judicial independence is not furthered by the possibility of impeachment and removal, but through that process certain forms of judicial misconduct can be checked. The presence in the constitutional mix of a design principle therefore tells us almost nothing about the extent to which its implementation will be limited because of possible abuse of power.

The application of this fundamental meta-principle (a principle about the implementation of principles) to Congress's power over jurisdiction is plain enough. That power is, among other things, a check on the judiciary. Whether such a limitation on judicial authority should be in the Constitution is a question of design on which commentators differ. Whether it is in the Constitution, however, cannot be answered by the observation (itself doubtful) that the Constitution reflects a design that federal jurisdiction extend as far as federal legislative power, any more than the question whether the President may be temporarily

\footnotetext{
${ }^{157}$ It is no answer to point out that cases about small amounts of money may involve major issues of law. That may be true, but whether resolution of every such question of law justifies dragging one of the parties to a distant federal court is another question, one the Constitution easily might leave to Congress. If questions of law cannot wait for a lawsuit that is worth a federal appeal, then the entire constitutional mechanism that limits the courts' declarations of law to actual cases and controversies is a bad idea and questions of law should be decided in the abstract. That way lies a Council of Revision.

$x$ There is nothing odd about the idea that the care of constitutional principles, especially constitutional principles that involve federal supremacy, may often safely be entrusted to Congress. Since 1789, Congress has largely looked favorably on the principle of coextensiveness.
} 
removed for disability by a collegial body can be answered by the observation that the presidency is unitary. ${ }^{139}$

Amar's arguments are alluring in part because they have both a form and a content congenial to many commentators on federal jurisdiction. The form is a reading that harmonizes the Constitution with some theoretical principle. The content, the theoretical principle, is that the federal courts are the special guardians of the Constitution. Madison, however, cautioned us that no theoretical principle is a substitute for a close examination of the Constitution's intricate clockwork. ${ }^{140}$ God is in the details.

\footnotetext{
${ }^{120}$ See US Const, Amend XXV (providing for temporary removal of President by Vice President and principal officers of executive departments).

${ }^{100}$ See Letter from Madison to Webster (May 27, 1830), in 4 Writings of Madison at 85 (cited in note 115).
} 